\title{
12- Yabancı uyruklu öğrencilerin uzaktan eğitim sürecinin değerlendirilmesi: Bir durum çalışması ${ }^{1}$
}

\author{
Musa ÇALIŞIR² \\ Hatice ÖZASLAN3
}

APA: Çalışır, M.; Özaslan, H. (2021). Yabancı uyruklu öğrencilerin uzaktan eğitim sürecinin değerlendirilmesi: Bir durum çalışması. RumeliDE Dil ve Edebiyat Araştırmaları Dergisi, (Ö10), 192-213. DOI: 10.2900o/rumelide.1011389.

\section{$\ddot{O} \mathbf{z}$}

$\mathrm{Bu}$ çalışmanın amacı ilkokula devam eden yabancı uyruklu öğrencilerin uzaktan eğitim sürecinin değerlendirilmesidir. Çalışmada nitel araştırma durum çalışması deseni kullanılmış, maksimum çeşitlilik örneklemi çerçevesinde 14 öğretmen ile yarı yapılandırılmış görüşmeler gerçekleştirilmiş ve doküman incelemesi yapılmıştır. Verilerin analizinde içerik analizi tekniği kullanılmıştır. Çalışma bulguları olarak uzaktan eğitim sürecinde MEB uygulamaları, uzaktan eğitimde ders süreci ve etkileyen faktörler ve beklenti ve çözüm önerileri olmak üzere 3 tema oluşmuştur. Uzaktan eğitim sürecinde Eba, TRT Eba TV, Eba destek noktaları, yaz kursları, hizmet içi eğitimler, materyal destekleri ve bilgilendirme çalışmaları uygulamalarının MEB tarafından hayata geçirildiği ancak bu uygulamaların yabancı uyruklu öğrenciler tarafından kullanılmadığı veya sınırlı kullanılabildiği sonucuna ulaşılmıştır. Uzaktan eğitimde ders sürecinde katılımın maddi durumlar, veli ilgisizliği ve dil sorunu sebepleriyle derslere katılımın azaldı̆̆ı, ders veriminin düştüğü, sınıf yönetimi ve aktif katılımı sağlama konusunda sorunlar yaşandığı görülmüştür. Ders sürecindeki verimin düşmesinde ise öğrencinin ev ortamının, program açısından yaşanan zorlukların, materyaller konusunda yaşanan zorlukların, veli ile iletişim ve dil sorunu faktörlerinin rol oynadığı sonucuna ulaşılmıştır. Katılımcı öğretmenlerin maddi sorunların aşılması, veli desteği, Eba içeriğine yabancı öğrencilere uygun içerikler eklenmesi, yabancı uyruklu öğrencilere uygun materyaller hazırlanması ve hizmet içi eğitimler verilmesi şeklinde beklenti ve çözüm önerilerinin olduğu görülmüştür.

Anahtar kelimeler: Uzaktan eğitim, mülteci, sığınmacı

\section{Evaluation of distance education process of foreign students: A case study}

\begin{abstract}
This study aims to evaluate the distance education process of refugee students in primary schools. Qualitative research, case study design was used in this study and semi-structured interviews were conducted with 14 teachers within the framework of maximum diversity sampling and document analysis was conducted. As the study's findings, three themes emerged as Minister of Education practices in the distance education process, the lesson process in distance education and the factors affecting it, lastly expectations and solution suggestions. In the distance education process, It has
\end{abstract}

Ondokuz Mayıs Üniversitesi, Sosyal ve Beşeri Bilimler Araştırmaları Etik Kurul Kararlarının 2021/406 sayılı yazısı ile araştırma için gerekli olan etik kurul izni alınmıştır.

Arş. Gör., Sakarya Üniversitesi, Eğitim Fakültesi, Temel Eğitim Bölümü, Sınıf Eğitimi ABD (Sakarya, Türkiye), mcalisir@sakarya.edu.tr, ORCID ID: oooo-0001-8647-9005 [Araştırma makalesi, Makale kayıt tarihi: 23.09.2021-kabul tarihi: 20.10.2021; DOI: 10.29000/rumelide.1011389]

3 Dr. Öğr. Üyesi, Ondokuz Mayıs Üniversitesi, Eğitim Fakültesi, Temel Eğitim Bölümü, Okul Öncesi Eğitimi ABD (Samsun, Türkiye), haticedizmanozaslan@yahoo.com, ORCID ID: oooo-0003-4902-951X

Adres | Address

RumeliDE Dil ve Edebiyat Araştırmaları Dergisi Osmanağa Mahallesi, Mürver Çiçeği Sokak, No:14/8 Kadıköy - ISTANBUL / TÜRKIYE 34714 e-posta: editor@rumelide.com

RumeliDE Journal of Language and Literature Studies Osmanağa Mahallesi, Mürver Çiçeği Sokak, No:14/8

Kadıköy - ISTANBUL / TURKEY 34714 tel: +90 $5057958124,+902167730616$

e-mail: editor@rumelide.com

phone: +90 505 7958124, +90 2167730616 
been concluded that Eba, TRT Eba TV, Eba point of support, summer courses, in-service training, material support, and informative works have been implemented by the Minister of Education, but these applications are not used by refugee students or can be used in a limited way. During distance education, participation in the lessons decreased due to financial situations, parental indifference, and language problems. The efficiency of the lessons decreased, and there were problems in classroom management and active participation. In the decrease of efficiency in the course process; It has been concluded because of that the student's home environment, the difficulties experienced in terms of the program, the difficulties in the materials, the communication with the parents, and the language problem factors play a role. It has specified that Participating teachers have some solutions offers such as overcoming financial problems, parent support, adding appropriate content to the EBA content for refugee students, preparing appropriate materials for refugee students, and providing in-service training.

Keywords: Distance learning, refugee, asylum seeker

\section{Giriş}

Çatışmalar, yoksulluk ve zulümler sebebiyle ülkelerini terk eden mülteci, göçmen ve sığınmacı insan sayısındaki hızlı yükseliş ve bu insanlara sunulması gereken eğitim, güvenlik, sağlık, konaklama gibi hizmetlerin sağlanılması dünyadaki pek çok devletin önemli sorunlarından biridir. Birleşmiş Milletler Mülteciler Yüksek Komiserliği (BMMYK)'nin raporuna göre 79.5 milyon zorunlu göçe maruz kalmış ve bu insanların \%73'ü komşu ülkelere sığınmıştır. Suriye'de patlak veren insanlık krizinin ardından 6.6 milyon Suriye uyruklu insan da zorunlu göçe maruz kalmıştır. Bu insanlar Lübnan, Ürdün, Irak, Mısır, Almanya, İsviçre ve Türkiye gibi ülkelere sığınmışlardır. Bugün en çok Suriye uyruklu vatandaşı ağırlayan ülke sınır komşusu olan Türkiye, aynı zamanda dünyada da en çok göçmeni misafir eden ülkedir (UNHCR, 2020a).

Ülkemiz 3.630.702 Suriyeli uyruklu vatandaşın yanı sıra, 40obinden fazla farklı milliyetten (Irak, Ürdün, Iran, Afganistan, Azerbaycan, Mısır, Özbekistan, Rusya gibi) insanlara da ev sahipliği yapmaktadır (GİGM, 2020; UNHCR, 2020b). BMMYK’ya göre dünya üzerinde zorunlu göçe maruz kalanların \%40’1 (30-34 milyon) çocuktur (UNHCR, 2020a). Göç İdaresi Genel Müdürlüğü (GİGM, 2020) verilerine göre ülkemizde bulunan 3.630.702 Suriye uyruklunun 1.696.943’ü yani yaklaşı \%47'sinin çocuk olduğu görülmektedir. Savaş, çatışma ve yoksulluk sebebiyle çocukların maruz kaldığı zorunlu göç, bu çocukların sağlı̆̆ı, eğitimi ve gelişimi açısından büyük bir engeldir (Derince, 2019; Diab, Palosaari ve Punamäki, 2018). Bu engellerin aşılabilmesi için bu çocukların en kısa sürede eğitimöğretim faaliyetlerine kazandırılması hem göç ettikleri ülkeye uyum ve adaptasyon açısından, hem de travma sahibi bu çocuklara okulun sunduğu güvenli ortam ve sosyal yaşamın iyileştirici etkisi açısından oldukça önemlidir (Ehntholt, Smith ve Yule, 2005; Eroğlu, 2020).

2011 yllından Arap Baharının etkisi ile zorunlu göçe maruz kalan bu çocukların eğitim ihtiyaçlarının giderilmesi için okullar açılmış, çeşitli projeler ile Türk ve Suriyeli öğretmenler istihdam edilmiş, Milli Eğitim Bakanlığı ve UNICEF işbirliği ile ders kitapları hazırlanıp ücretsiz şekilde dağıtılmış ve programlar hazırlanmıştır (Yavuz ve Mızrak, 2016). Acil ve geçici eğitim ihtiyacının karşılanması sebebi ile Geçici Barınma Merkezlerinde (GBM) ve Geçici Eğitim Merkezleri (GEM) kurulmuş ve ilk aşamada Arapça olarak eğitim öğretim faaliyetleri hızla başlamıştır. GEM ve GBMlerde sadece Suriyeli değil, Arap coğrafyasından ülkemize göç etmiş Iraklı, Filistinli, Mısırlı çocuklar gibi pek çok yabancı uyruklu öğrenci faydalanmıştır. 2016 yllından itibaren bu merkezlerde Türkçe öğretim faaliyetleri de eklenerek Arapça

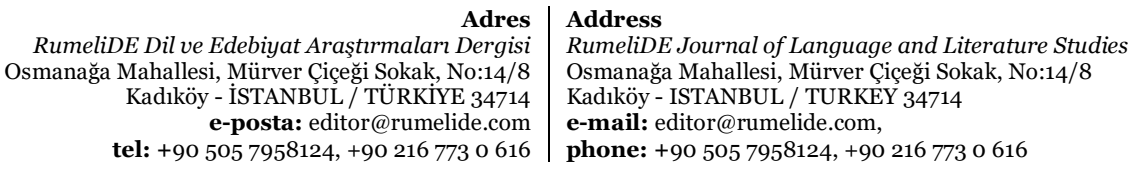


müfredata 5 saat Türkçe öğretimi de eklenmiş, 2016-2017 eğitim öğretim yılı ile Türkçe öğretimi dersi 15 saate çıartılmıştır. Aynı zamanda 2016-2017 eğitim öğretim yllı itibariyle acil eğitim hizmetleri sağlamak için kurulan GBM ve GEMlerin kapatılma süreci başlamış, bu öğrenciler devlet okullarına nakledilmeye başlanmıştır. 2014-2016 Eğitim öğretim yllında 421 olan GEM sayısı 2019 yllında 23’e kadar düşmüş, yabancı uyruklu öğrenciler devlet okullarına aktarılmıştır (HBOGM, 2020; OMDUSMANLIK, 2018). Ancak hızla devam eden entegrasyon süreci küresel pandemi sebebiyle uzaktan eğitim sistemine taşınmak zorunda kalmıştır.

Çin’in Vuhan kentinde aralık sonralarında bir grup hasta üzerinde yapılan araştırmalar sonucunda tespit edilen yeni Koronavirüs (SARS-CoV-2), Vuhan'dan başlayarak tüm Çin Halk Cumhuriyeti’ne ve diğer dünya ülkelerine yayılmış ve Dünya Sağlık Örgütü (WHO) tarafından 11 Mart 2020 tarihinde salgın, pandemi olarak ilan edilmiştir (TUBİTAK, 2020). Salgının bulaşıcılı̆̆ı ve ölümcül sonuçları olması sebebiyle ülkeler salgının yayılma hızı ve etkisi azaltmak amacıyla ciddi tedbirler almaya başlamıştır. Ülkemizde de sokağa çıkma yasakları, toplu etkinliklerin kısıtlanması, maske takma zorunluluğu gibi tedbirler yürürlüğe konarak salgın ile mücadele edilmektedir ("T.C. İçişleri Bakanlığı", 2021). Bu salgının yayılmasının önlenmesinin adına alınan önemli tedbirlerden biri de toplu bir alan olan ve toplumun farklı kesimlerinin bir arada bulunduğu eğitim kurumlarının kapatılması olmuştur. Ancak eğitimin devam etmesi gerektiğinde uzaktan eğitim sistemine geçilmiştir (MEB, 2020). Uzaktan eğitim sistemi getirdiği yararlar dışında teknolojik yetersizliklere ve sorunlara, öğrencilerin devamsızlık sorunlarına, ölçme ve değerlendirme sorunlarına, firsat eşitsizliğine ve uzaktan eğitim sistemine uyum sorunları gibi sorunlara yol açmıştır (Saygı, 2021).

Alan yazını incelendiğinde Türk öğrencilerin uzaktan eğitimde yaşadığı sorunlar, güçlükler ve önerilerle ilgili pek çok çalışma yapılmış olmasına karşın, yabancı uyruklu öğrencilerin uzaktan eğitim sürecinin değerlendiren çalışmaların çok sınırlı olduğu görülmüştür. Ülkemizde çok sayıda yabancı uyruklu öğrenci olduğu bilinmekte ve alan yazı incelendiğinde yüz yüze eğitim sisteminde yabancı uyruklu öğrencilerin okulda dil, uyum, duyuşsal, bilişsel, akademik, maddi, öğretim programı, materyal ve nitelikli öğretmen gibi konularda sorunlar yaşadığı görülmektedir (Alyılmaz, 2010; Boylu ve Işık, 2020; Cırıt Karaağaç ve Güvenç, 2019; Ergen ve Şahin, 2019; Kamer ve Sarıahmetoğlu, 2020; Kara, Tiğit ve Ağırman, 2020; Koehler ve Schneider, 2019; Özenç ve Saat, 2019; Rousseau, Drapeau ve Corin, 1996; Tunga, Ergin ve Çağıltay, 2020). Örgün eğitimde bile dört temel dil becerisinde yetersizlik yaşayan yabancı uyruklu öğrencilerin tüm dünyada Covid-19 salgını sebebiyle uygulanmaya başlanan uzaktan eğitim sürecinde de ilgili becerilerde yetersizliklerinin devam etmesi ve uzaktan eğitim sisteminin getirdiği olumsuz etkilerin yabancı uyruklu öğrenciler tarafından da hissedilmesi kaçınılmazdır. Bu sebeple bu çalışmanın amacı ilkokula devam eden yabancı uyruklu öğrencilerin uzaktan eğitim sürecinin değerlendirilmesidir. Çalışmanın önemi ise yabancı uyruklu öğrencilerin uzaktan eğitim sürecine bütüncül şekilde ışık tutmasıdır. Bu araştırmada aşağıdaki sorulara cevap aranmıştır;

-Yabancı uyruklu öğrencilere yönelik pandemi sürecinde MEB uygulamaları neler ve içerikleri nasildır?

-Yabancı uyruklu öğrencilerin uzaktan eğitim sürecinde karşılaştıkları zorluklar nelerdir?

-Yabancı uyruklu öğrencilere yapılan uzaktan eğitim sürecinin etkililiği için neler yapılabilir?

\section{Yöntem}

Araştırmada nitel araştırma desenlerinden biri olan durum çalışması (case study) deseni kullanılmıştır. Durum çalışması güncel yaşamdaki sınırları belli bir durum hakkında çoklu bilgi kaynakları kullanılarak

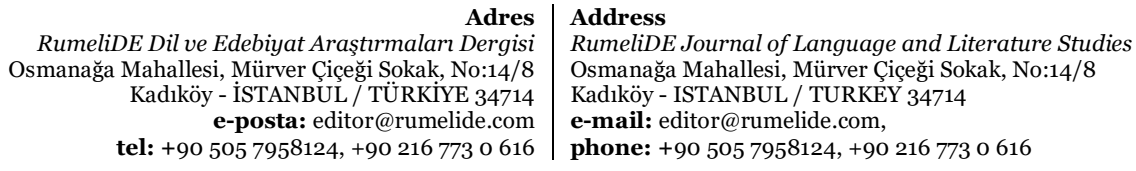


detaylı ve derinlemesine bilgi topladı $\breve{g} ı$ ve bir durum betimlemesi ortaya koyduğu nitel bir yaklaşımdır (Creswell, 2020). Bu araştırmada yabancı uyruklu öğrencilerin belirli bir durum olan pandemi dönemindeki uzaktan eğitim faaliyetleri görüşme ve doküman analizi kullanılarak derinlemesine incelenmek istendiğinden durum çalışması tercih edilmiştir.

\section{1 Çalışma grubu}

Araştırmada örnekleme yöntemlerinden maksimum çeşitlilik örneklemi kullanılmıştır. Maksimumum çeşitlilik örneklemi araştırmada incelenmiş olan çeşitli boyutlarla ilgili geniş bir yelpazede amaçlı olarak seçmek, farklılık çeşitlilikleri araştırmaya dahil etmektir (Patton, 2018). Yabancılara uzaktan eğitim sürecinde çeşitli sınıf kademeleri ve farklı uygulamalardaki çeşitliliğin de araştırmaya aktarılması istendiğinden maksimum çeşitlilik örneklemi tercih edilmiştir.

Türkiye'de ilkokullarda yabancllara eğitim faaliyetleri örgün eğitim ve Suriyeli Öğrencilerin Türk eğitim Sistemine Entegrasyonu Projesi (PIKTES) olmak üzere 2 şekilde sürdürülmektedir. Örgün eğitim sistemi bilinmekle beraber Piktes kapsamında örgün eğitimde Türkçe dil becerileri konusunda yetersiz olan öğrenciler uyum sınıflarına alınmakta ve sadece yabancı uyruklu öğrencilere Türkçe dil becerilerinin geliştirilmesi amacıyla sınırlı süreli özel bir eğitim verilmektedir. Bu nedenle araştırmanın çalışma grubunu her 2 grubu da içine alacak şekilde Sakarya ilinde sınıfında yabancı uyruklu öğrenci bulunan 8 sınıf öğretmeni ve Piktes kapsamında görev yapmakta olan 6 öğretmen oluşturmaktadır. Çalışmanın ileriki aşamalarında bu iki farklı grup arasındaki çeşitli farklılıklar da açılanacağından sınıfında yabancı uyruklu öğrenci bulunan ve örgün eğitim veren 8 sınıf öğretmeni “örgün eğitim veren öğretmenler” şeklinde tanımlanmıştır. Örgün eğitim veren öğretmenlerde çeşitlilik olması amacıyla ikişer 1., 2., 3. ve 4. Sınıf öğretmeni ile çalışılmıştır. Araştırma kapsamında görüşme gerçekleştirilen öğretmenlerden Piktes Projesinde görev yapan öğretmenler P.1, P.2....., örgün eğitim veren öğretmenler ise Ö.1, Ö.2, Ö.3... şeklinde kodlanmıştır.

\subsection{Veri toplama yöntemi}

Araştırma kapsamında kullanılan ilk veri toplama yöntemi yarı yapılandırılmış görüşmelerdir. Yarı yapılandırılmış görüşme, yarı yapılandırılmış görüşme sorularıyla gerçekleştirilen, esnek, katılımcılardan spesifik verilerin toplanıldığı, önceden belirlenmiş ifade ve soru ayrıntılarının olmadığı görüşme metodudur (Merriam, 2018). Bu araştırmada yarı yapılandırılmış görüşme, görüşme sorularını sürece göre güncellenebiliyor olması sebebiyle esnekliğinden ve katılımcılardan detaylı veriler toplanmak istendiğinden tercih edilmiştir.

Görüşmeler pandemi sebebiyle online ortamda gerçekleşmiştir. Online ortamda gerçekleşen görüşmelerde öncelikle çalışma hakkında detaylı bilgi verilmiş, araştırmanın amacı, önemi ve sebebi belirtilmiştir. Ardından toplanacak tüm verilerin gizli kalacağı, isimlerinin hiçbir suretle paylaşılamayacağı ve çalışmada kodlanarak kullanılacağı belirtilmiştir. Ardından katılımcı öğretmenlerle kısa bir sohbet gerçekleştirerek katılımcıların araştırmacıya güven duymaları, samimiyet hissetmeleri ve kaygılarının ortadan kalması sağlanmıştır. Görüşme sırasında tüm katılımcılar ile araştırmacının kameraları açık bulunmuş ve bu sayede beden dili ile etkili iletişim sağlanmasına özen gösterilmiştir.

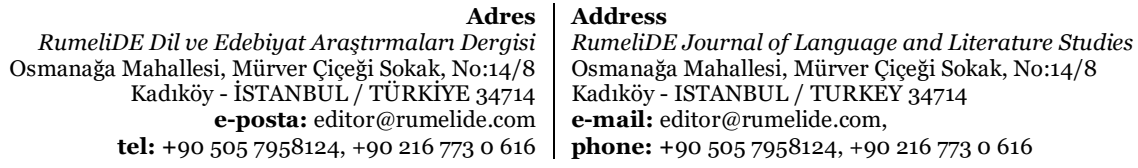


Temel görüşme soruları daha detaylı yanıtlar almak ve derinliği arttırmak adına sonda sorularla desteklenmiştir. Araştırma kapsamında yapılan görüşmelerin süresi, katılımcının konuya hakimiyet ve kişisel özelliklerine göre değişmeler göstermekle beraber görüşmeler ortalama 35-40 dk. sürmüştür.

Araştırmada kullanılan diğer bir veri toplama yöntemi ise doküman incelemesidir. Doküman incelemesi araştırma ile ilgili yazılı ve görsem materyal ve malzemelerin de araştırmaya dahil edilmesidir (Yıldırım ve Şimşek, 2018). Uzaktan eğitim sürecinde bahsedilen kaynak ve materyaller ve görüşlerin desteklenmesi amacıyla doküman inceleme yöntemi kullanılmıştır. Bu kapsamda Eba içeriği, Eba Tv'de yabancı uyruklu öğrenciler için oluşturulan içerikler ve yapılan çalışmalar hakkındaki medyada yer alan içerikler incelenerek araştırmaya dahil edilmiştir.

\subsection{Verilerin analizi}

Veriler analiz edilirken içerik analizi kullanılmıştır. İçerik analizi elde edilen verilerden elde edilen kodların birbirine belirli benzer temalar altında bir araya getirilerek yorumlanmasıdır (Yıldırım ve Şimşek, 2018). Araştırmada elde edilen verilerden önce kodlar elde edilmiş ve kodlardan temalar bulunmuştur. Nitel verilerin analizinde MAXQDA 2020 programı kullanılmıştır.

\subsection{Geçerlilik ve güvenilirlik}

Nitel araştırmalarda inandırıcılık, aktarılabilirlik, tutarlılık ve teyit edilebilirlik ölçütleri sayesinde geçerlilik ve güvenilirlik sağlanır. Araştırmada inandırıcılığın sağlanabilmesi için araştırmacının elde ettiği bulguların geçerliliğine, benzer ortamlarda sonuçların geçerliliğine, süreçlerin birbiriyle tutarlı olduğuna ve verilerin nesnel bir yaklaşımla ortaya konulduğu hakkında kanıtlar sunması gerekir (Yıldırım ve Şimşek, 2018). Bu çalışmada inandırıcılığın sağlanabilmesi amacıyla; derinlik odaklı veri toplama, çeşitleme, uzman incelemesi ve katılımcı teyidi yöntemleri kullanılmıştır. Derinlik odaklı veri toplama kapsamında Piktes projesinde görev yapan öğretmenler bir grup diğer iki okulda görev yapan öğretmenler bir grup olarak veriler toplam iki grupta farklı zamanlarda ve toplu olarak kodlanmıştır. Bu sayede görüşme yapılan iki grubun bahsettiği farklı durumlar ve örüntüler fark edilmeye çalışılmıştır. Çeşitleme kapsamında veri kaynaklarında çeşitleye gidilmiştir. Araştırmaya ilkokul sürecindeki tüm sınıf öğretmenlerinin katılımı sağlanmış, ayrıca yabancı uyruklu öğrencilerle çalışan diğer bir grup olan Piktes öğretmenleri de dahil edilmiştir. Uzman incelemesi yönteminde ise hazırlanan araştırma problemi, soruları ve görüşme soruları iki alan uzmanına gönderilmiş ve uzmanların araştırmayı çeşitli boyutları ile incelemesi sağlanmıştır. Katılımcıların bahsettikleri hususlar her görüşme sorusunun ardından kısaca birkaç cümle ile özetlenmiş ve katılımcıların teyidi alınmıştır.

\section{Bulgular}

$\mathrm{Bu}$ bölümde araştırmada elde edilen bulgular açılanacaktır. Katılımcı öğretmenlerin görüşleri incelendiğinde görüşlerin "Uzaktan Eğitim Sürecinde MEB Uygulamaları”, "Uzaktan Eğitimde Ders Süreci” ve "Beklenti ve Öneriler” olmak üzere üç tema altında birleştiği görülmüştür.

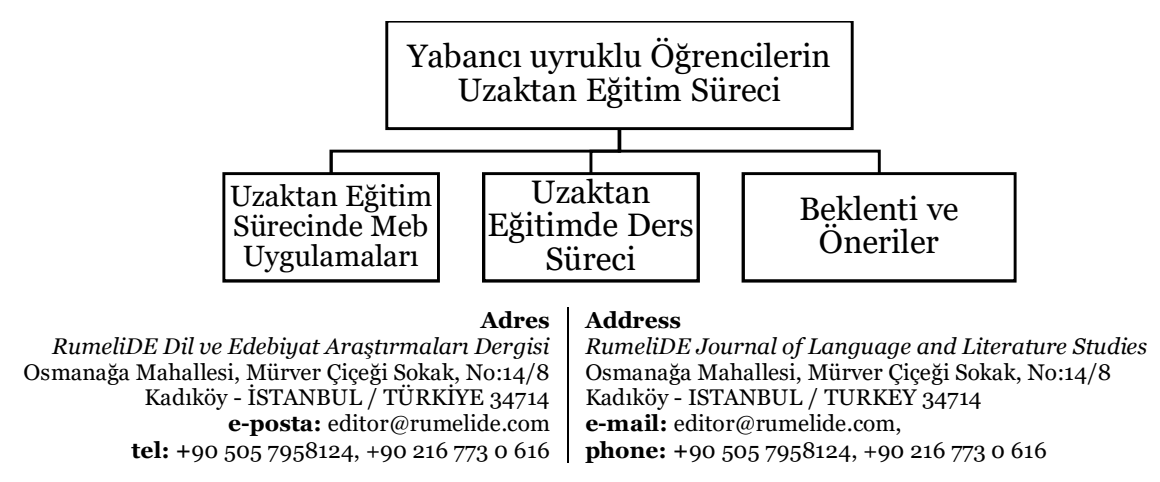


Şekil 1: Bulgular kapsamında oluşan temalar

\subsection{Uzaktan eğitim sürecinde MEB uygulamaları}

Uzaktan eğitim sürecine geçildiği andan itibaren Millî Eğitim Bakanlığı çeşitli faaliyet ve uygulamalar ile uzaktan eğitime uyum ve entegrasyonu sağlamaya çalışmış, uzaktan eğitim faaliyetlerinin düzenli ve verimli şekilde gerçekleştirilmesi, fırsat eşitliği yaratılması adına çeşitli uygulamaları hayata geçirmiştir. Uzaktan eğitim sürecinde Millî Eğitim Bakanlığının hayata geçirdiği ve öğretmenlerin yabancı uyruklu öğrencilerin eğitimi sürecinde faydalandığı çeşitli uygulamalar değerlendirilmiştir.

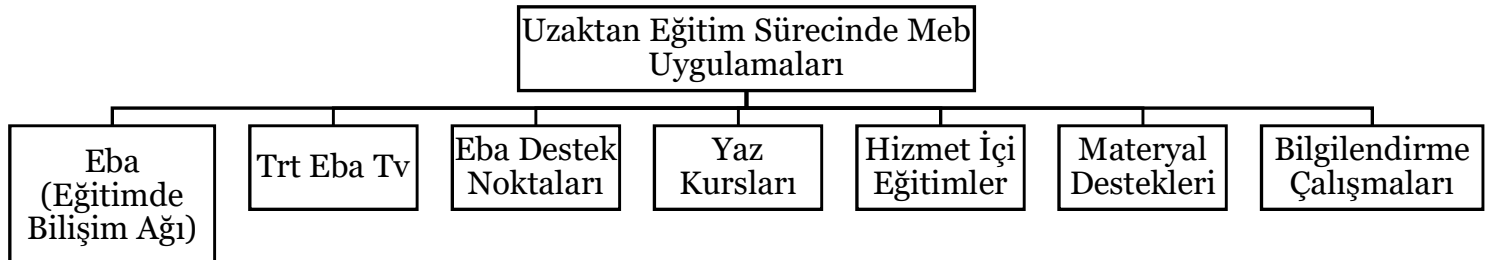

Şekil 2: Uzaktan eğitim sürecinde MEB uygulamaları

\subsubsection{Eba (Eğitim bilişim ağı)}

Katılımcı öğretmenlerin Eba hakkındaki görüşleri incelendiğinde Eba içerisinde bulunan materyallerin matematik, fen bilgisi gibi derslerin somutlaştırılması amacıyla faydalı olduğunu ve derslerinde aktif şekilde kullandıklarını belirtmişlerdir. Örgün eğitim veren öğretmenler Eba içeriğinin dolu olduğunu çeşitli konu başlıklarında eksiklikler olsa da genel hatları ile içeriği beğendiklerini ve "geniş bir yelpazeye" sahip olduğunu ancak Eba sisteminden kendi derslerinde aktif olarak faydalanıyor olsalar da öğrencilerin bireysel olarak faydalanmasının ön şartının yeterli Türkçe dil bilgisine sahip olmak olduğunu belirtmişlerdir. Öğrencilerin Türkçe dil yeterliliğine sahip olmadığı durumlarda Eba'dan faydalanamadıklarını paylaşmışlardır. Öğrencilerin dil becerilerini geliştirmeyi amaçlayan Piktes öğretmenleri ise Eba içeriğinin yabancı uyruklu öğrencilere Türkçe dil yeterliliği kazandırması konusunda zayıf bulmuşlardır. Bu konu ile ilgili öğretmenler Eba içerisindeki okuma-yazma etkinliklerinin yabancı uyruklu öğrencilerde kullanılabileceğini ve kullandıklarını ancak "selamlaşma" gibi konuşma dil becerisi hakkındaki etkinlikler aradıklarında anasınıfı seviyesinde etkinlikler bulabildiklerini ve bu etkinliklerin de dil becerisi kazandırmak adına çocukların seviyesine uygun olmadığını söylemişlerdir. Eba içerisinde daha önce yabancı uyruklu öğrencilere Türkçe öğretimi için bir ders ya da konu başlığının bulunmadığını belirten öğretmenler, 2020-2021 eğitim öğretim yılı 2. Döneminde "Yabancı Öğrenciler İçin Türkçe” isimli bir dersin Eba'ya eklendiğini ancak bu dersin içeriğinde herhangi bir materyal bulunmadığını belirtmişlerdir. Yapılan araştırma kapsamında Eba sistemine girildiğinde "Yabancı Öğrenciler İçin Türkçe" dersi olduğu görülmüştür. Eba içerisinde bu dersin A.1.1, A.1.2, A.1.3, A.1.4, A.2.1, A2.2 şeklinde 6 farklı seviyeye ayrıldı̆̆ görülmüştür. Ders içeriklerine kazanımlar için başlıklar açıldığı ancak başlıklar içerisinde herhangi bir materyalin bulunmadığı tespit edilmiştir. Ayrıca katılımcı öğretmenler Eba içerisinde yabancılara Türkçe öğretimi ile ilgili materyaller aradıklarında "aradıklarını bulmakta güçlük çektiklerini" ve "yabancı uyruklu öğrencilerin bu materyallere ulaşırken kafası karışabileceğini ve çocuklara sistemin karmaşık gelebileceğini” belirtmişlerdir. Yine Eba içerisinde “yabancılara Türkçe öğretimi” anahtar kelimesi arandığında konu ile alakasız etkinlik ve videolar ile karşılaşılmıştır. Eba ile ilgili Ö.4 ve Ö.8 şu yorumlarda bulunmuşlardır;

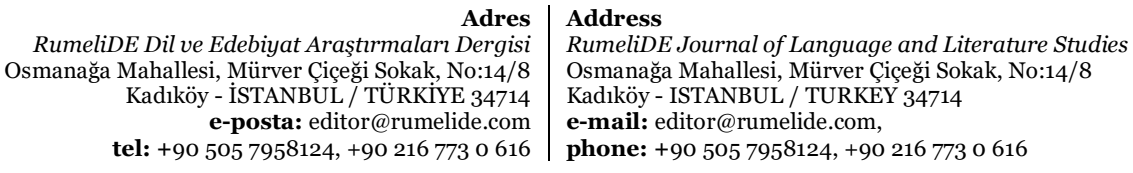




\begin{abstract}
"Hani bizim dilimizi tam olarak anlayabilen çocuk net olarak onları yapabilir. Hani uygun olmaması için hiçbir neden yok, çünkü ben dersi anlatırken o yabancı uyruklu öğrenci benden öyle ne biliyorsa aynı şekilde oradan doğru erişim aracılığıyla öğrenebilir, yapabilir yani öğrenemeyecek bir şey yok.” Ö.4

"Birinci sınıftan dördüncü sınıfa kadar okumuş ilerlemiş bir çocuk için olabilir ama onun dışında ara sınıftan gelmiş tam dil bilmiyor tam adapte olamamış çocuklar için uygun değil.” Ö.8
\end{abstract}

Eba içerisinde yer alan ve yabancı uyruklu öğrencilerin dil gelişimini amaçlayan diğer bir çalışma da Dil Öğrenim Portalıdır. Portal hakkında görüşleri sorulduğunda katılımcı öğretmenlerden sadece 4 kişinin bu portal hakkında bilgiye sahip olduğu görülmüştür. Bu 4 katılımcıdan 2 kişi bu Portalı kullandığını 2 kişi ise sadece bilgi sahibi olduğunu belirtmiştir. Bu katılımcılar Dil Öğrenim Portalının yabancı uyruklu öğrenciler için uygun olduğu belirtmişlerdir. Eba Dil Öğrenim Portalı hakkında bilgi sahibi olduğu görülen 2 katılımcı ise "göz attığını" ancak aktif şekilde kullanmadığını ve öğrencileri yönlendirmediğini belirtmiştir. Eba Dil Öğrenim Portalı incelendiğinde Eba anasayfasında ya da öğrencilerin giriş yaptıklarında karşılarına çıkan ekranda "Dil Öğrenim Portalı" gibi bir ifadenin yer almadığı görülmüştür. Eba içerisinde "dil öğrenim portalı" anahtar kelimesi arandığında da portala ulaşılamamaktadır. Dil Öğrenim Portalına anasayfada yer alan "hızlı erişim" sekmesinden ulaşlabilinmiştir. Dil öğrenim portalı incelendiğinde portalda Türkçe öğretimi ile ilgili 5 farklı uygulamanın yer aldığı, destek materyaller bölümünde Türkçe öğretimi ders kitaplarının, hikâye kitaplarının, sınavlar-testler ve çalışma kağıtlarının, sözlüklerin ve program ile planların bulunduğu görülmüştür. Aynı zamanda portalda etkinlikler ve ders anlatımları şeklinde iki farklı başlık daha olduğu görülse de bu başlıklar aktif halde değildir. Dil öğrenim Portalı içeriği incelendiğinde uygulamaların oyunlaştırıldığı ve genel hatları ile yabancılara Türkçe öğretiminde uygun olduğu görülmüştür. Okuma yazma süreci ile ilgili eğitici uygulamanın yanı sıra temel günlük hayattaki kavramların öğretimi için de uygulamaların bulunduğu görülmüştür. Dil Öğrenim Portalında öğrencilerin çeşitli yabancılara Türkçe öğretimi ders kitaplarına ve özellikle yabancılara Türkçe öğretimi için hazırlanmış hikâye kitaplarının pdf, ses dosyası ve e-kitap hallerine ulaşabilmektelerdir.

\title{
3.1.2 TRT Eba Tv
}

TRT Eba Tv, uzaktan eğitime erişemeyen öğrencilerin eğitimlerin kopmaması ve firsat eşitliği amacıyla kurulan Eba Tv; televizyon ve internet yayını yapılmakla beraber yapılan yayınların geçmişe dönük videoların online ortamda Eba sistemi üzerinden de izlenebildiği bir platformdur. Katılımcı öğretmenler Eba Tv uygulamasının olumlu olduğu konusunda fikir birliğine sahip oldukları görülmüştür. Eba Tv’nin çocukların ilgisini çekmediği ve sıradan bir ders anlatımı olduğunu söyleyen birkaç katılımcı da olmuştur. Katılımcı öğretmenlerin tamamı uzaktan eğitim derslerine katılım sağlayamayan öğrencilerini Eba Tv'ye yönlendirdiklerinden bahsetmişlerdir. Eba Tv içeriğinin yabancı uyruklu öğrenciler için uygun olduğunu belirten öğretmenler, yakın zamanda Eba Tv'de yabancı uyruklu öğrenciler için özel derslerin de başladığını ve bu derslerin içeriklerinin oldukça güzel olduğunu ve derslerinde de kimi zaman bu içerikleri materyal olarak kullandıklarını, kimi zaman ise öğrencilere "takviye" olarak izlemelerini istediklerini belirtmişlerdir. Ancak Eba Tv'ye öğrencileri yönlendirmiş olsalar dahi öğrencilerin "çok azının” Eba Tv'yi takip ettiğini belirtmişlerdir. Katılımcı öğretmenlerin tamamı yönlendirilen öğrencilerin Eba Tv’yi takip edip etmediği konusunda kendilerine bir "geri dönüş” yapılmadığını belirtmiş, öğrencilerinin Eba Tv'den ne denli faydalandıklarını bilmediklerini söylemişlerdir. Trt Eba Tv ile ilgili Ö.5 Ö.7 ve şu yorumlarda bulunmuşlardır;

"Benim bile ilgimi çekmedi, çocukların ilgisini hiç çekmedi. Çok renkli ama o renkler çok karışıtı ben öyle düşünüyorum.” Ö.5

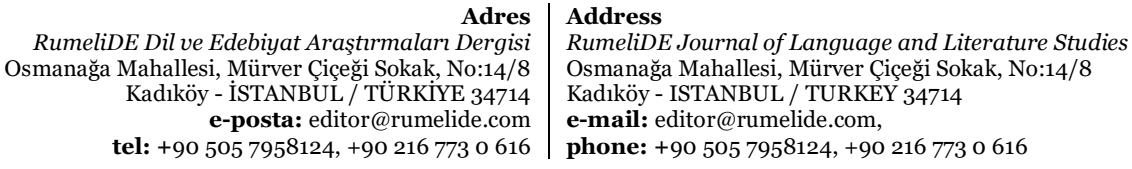


"Biraz videolar bu yaş grubundaki çocuklar için, YouTube TikTok gibi yerlerden çok fazla içeriğe ulaştıkları için, eski tip gibi, eski zaman videoları gibi geldi bana. Mesela okulistik vardı, o daha eğlenceli geldi çocuklara. Eba’yı o yüzden istemediler.” Ö.7

Eba Tv yayın akışı incelendiğinde 2020-2021 eğitim öğretim yllı ikinci döneminden itibaren Eba Tv yayın akışına “1-2-3-4 Yabancı Öğrenciler İçin Türkçe” isimli bir dersin eklendiği görülmüştür. Bu dersin salı, çarşamba ve perşembe günleri yeni bölümlerinin, aynı günlerin akşamı ve hafta sonları ise tekrarının yayınlandığı görülmüştür. Ders içeriğine Eba sisteminden de ulaşılabilmektedir. Ders içeriği incelendiğinde temiz ve yavaş Türkçe konuşulduğu, Türkçe seviyesinin çocukların seviyesine uygun olduğu ve görseller ile beden dilinin yoğun şekilde kullanıldığı görülmüştür.

\subsubsection{Eba destek noktaları}

Eba Destek Noktaları Millı̂ Eğitim Bakanlığı tarafindan maddi yetersizliklerden dolayı uzaktan eğitime erişemeyen öğrencilerin uzaktan eğitime erişmesi amacıyla okullarında ya da çeşitli mekanlar kurulan diğer bir uygulamadır. Eba Destek Noktalarını hakkında katılımcı öğretmenler Eba Destek Noktalarının okullarında kurulduğunu ve faaliyetlerine devam ettiğini ancak yabancı uyruklu öğrencilerinin maddi yetersizliklere sahip olup uzaktan eğitime erişim sağlayamasalar dahi Eba Destek Noktalarından faydalanmadıklarını belirtmişlerdir. Öğretmenler öğrencilere Eba Destek Noktaları hakkında bilgi verdiklerini ancak "insan sirkülasyonu olduğu için sağlık çekinceleri" ya da "kalabalık ailelere sahip olduklarından dolayı öğrenciyi Eba Destek Noktasına getiremedikleri” gibi sebeplerden ötürü öğrencilerin bu uygulamadan faydalanmadıklarını düşünmektelerdir. Ayrıca katılımcı öğretmenlerden Ö.4 Eba destek noktaları hakkında ilgi çekici bir görüş olarak "ders saatlerinin esnek olduğunu, kimi zaman akşam ders yaptıklarını ve bu saatlerde okulun kapalı olduğunu ya da sokağa çıkma yasaklarının başladığını" belirtmiştir. Eba destek noktaları ile ilgili Ö.3 şöyle bir yorumda bulunmuştur;

"Destek noktasına gittiler de yeteri kadar gitmediler. Yani birkaç gün gittiler. Ardından ilgili olmadığını düşünüyorum. Eba destek noktasında görevli kişilerin ilgili olduğunu düşünmüyorum. Gerekli ilgiyi bireysel olarak hani açma, kapama teknoloji anlamında gerekli donanımı sağlanmadığını düşünüyorum. Çünkü internet eksikliği vardı. Bazı noktalarda gerekli yerde ilgi olmadı.” Ö.5

\subsubsection{Yaz kursları}

Milli Eğitim Bakanlığının yabancı uyruklu öğrencilerin eğitimi konusunda yaptığı diğer bir uygulama da yaz kurslarıdır. Piktes kapsamında gerçekleştirilen yaz kursları, okuldaki yabancı uyruklu öğrencilerin yaz döneminde eğitim-öğretim faaliyetlerinden uzaklaşmamalarını ve geri kaldıkları noktalarda destek sağlamayı amaçlamaktadır. Pandemi nedeniyle uzaktan eğitime geçiş yapılmasının ardından 2020 yazında yabancı uyruklu öğrenciler için yaz kursları yine faaliyetlerine devam etmiştir. Yaz kursları sadece Piktes Projesinde görevli bir öğretmenin olduğu okullarda açıldığından dolayı örgün eğitim veren öğretmenlerden bu konuda fikir alınamamıştır.

Yaz kursları hakkında yaz kursunda görev alan ve bu faaliyetlerden öğrencilerinin faydalandığı öğretmenlerin yaz kursları hakkında "verimli olduğu" ve "verimsiz olduğu" şeklinde 2 farklı görüşe sahip olduğu görülmüştür. Yaz kurslarının verimli olduğunu belirten öğretmenler; dönem bittikten sonra Eba üzerinden yaz kursu faaliyetlerine başladıklarını ve yaz kurslarında öğrencilere gerek konu tekrarının yapıldığı gerekse Türkçe dil becerileri konusunda çalışmalar yapıldığından dolayı öğrenciler açısından "faydalı olduğunu" belirtmişlerdir. Yaz kurslarının verimsiz olduğunu belirten öğretmenler ise "yaz tatili döneminde çocukların oyun ihtiyacı olduğunu”, "öğrencilerin yaz döneminde eğitim-öğretim faaliyetleri konusunda motivasyon düşüklüğü yaşadıklarını” ve bu sebeplerden ötürü katılımın düşük olduğunu

\section{Adres Address}

RumeliDE Dil ve Edebiyat Araştırmaları Dergisi $\quad$ RumeliDE Journal of Language and Literature Studies

Osmanağa Mahallesi, Mürver Çiçeği Sokak, No:14/8 $\quad$ Osmanağa Mahallesi, Mürver Çiçeği Sokak, No:14/8

Kadıköy - ISTANBUL / TURKIYE 34714 Kadıköy - ISTANBUL / TURKEY 34714

e-posta: editor@rumelide.com $\quad$ e-mail: editor@rumelide.com,

tel: +90 505 7958124, +90 216773 o 616 phone: +90 505 7958124,+90 2167730616 
belirtmişlerdir. Ayrıca öğretmenler yaz kurslarına okul genelindeki her seviyeden yabancı uyruklu öğrencilerin katıldığından dolayı "seviye farklılığı” oluştuğunu ve bu durumda öğrencilerin bildiği konuları tekrar etmek istemediğini belirterek katılımın azaldığını söylemişlerdir. Yaz kursları ile ilgili P.2 şöyle bir yorumda bulunmuştur;

"Yaz kursu, yaz kurslarını ben verimli bulmuyorum. Neden? Çünkü bütün öğrenciler yaz tatilinde iken onları okula gelmeye mecbur bırakmak onlara haksızlık oluyor açıkçası. Hani sürekli soruyorlar hocam biz niye dersteyiz? Biz niye okuldayız? Biz neden geliyoruz? Bizim tatile ihtiyacımız var diye sorguluyorlar sürekli. Söyleyecek bir şey bulamıyorsunuz.Ben yazın ders olmasına mantıklı görmüyorum, verimli bulmuyorum.” P.2

\title{
3.1.5 Hizmet içi eğitimler
}

Katılımcı öğretmenlerin tamamına yakını pandemi döneminde çeşitli hizmet içi eğitimlere katıldıklarını belirtmişlerdir. Yapılmış olan çalışmalar arasında "kullanabilecekleri şeyler ile ilgili oldukça faydalı" eğitimlerin olduğu belirten öğretmenler, özellikle uzaktan eğitim ile ilgili olan hizmet içi eğitim faaliyetlerini oldukça faydalı olduğunu söylemişlerdir. Alınan hizmet içi eğitimlerin içeriği ile ilgili "web 2.o araçlarının kullanımı", "materyal hazırlama” gibi çeşitli eğitimler aldıklarını belirtmişlerdir. Hizmet içi eğitimler konusunda örgün eğitim veren öğretmenler ile Piktes projesinde görev yapan öğretmenlerin farklı eğitimler aldığı görülmüştür.

$\mathrm{Bu}$ konuda yapılan araştırmalar sonucunda, Piktes projesinde görev yapan öğretmenlere "uzaktan Türkçe öğretiminde materyal hazırlama", "okuduğunu anlama becerisinin ölçülmesi”, "kriz ve krize karşı müdahale” gibi eğitimleri doğrudan yabancı uyruklu öğrencilerin uzaktan eğitim sürecinde kullanılabilecek eğitimler verildiği görülmüştür. Bu eğitimlerin sadece Piktes projesi kapsamına özgü olduğu ve her öğretmenin katılımına açık olmadığı bilinmektedir. Örgün eğitim veren öğretmenlere ise çeşitli hizmet içi eğitimler sunulduğu ancak alacakları eğitimleri kendilerinin belirdiğinden bahsetmişlerdir. Bu hizmet içi eğitimler arasında "yabancı dil olarak Türkçe öğretimi” hakkında bir eğitimin de bulunduğu belirtmiştir. Ancak bu eğitimden örgün eğitim veren sadece üç öğretmen faydalandığını belirtmiş, geri kalan öğretmenler bu eğitimi almadıklarını belirtmişlerdir. Bu eğitimin içeriğinin "empati kazandırma" ve "selamlaşmanın öğretimi temel dil bilgisi etkinlikleri” gibi konulara sahip olduğunu belirtmişlerdir. Hizmetiçi eğitimlerle ilgili Ö.2 sahadaki durum ve aldığı eğitim arasındaki çelişkiyi şu şekilde ifade etmeye çalışmıştır;

\begin{abstract}
"Daha çok etkinliklere yönelik tanıma, tanışma yani öğrencinin kendini ifade etmesi, ondan sonra kendisinin yaşadığı psikolojiyi öğretmenin anlaması noktasında. Hani böyle bir şey bir süreçten normal bir süreçten geçilmediği için onlar açısından. Yani empati duygusunu daha çok öğretmenin geliştirip, yani çocuğu o noktayla değerlendirip anlama şeyi bize verilen eğitim daha çok bu tarzdaydı. Ama yani inanın sahada çok farklı, sahadaki durum böyle bir durum değil. Yani şunu diyorsun; ya benim bu insanlara yardımcı olmam lazım. Bunlar savaşın çocukları, bunlar bir mağdur insanlar. Bir gariplik ya da bir şeyler hissetmessinler diye, ama sahadaki durum yani dediğim gibi çok farklı yani. Onlar kendilerine böyle bir ezik ya da ssey hissettikleri bir durum yok. Yani bu anlamda yaklaşllıyor. Bence eğitimlerinin daha farklı bir yoldan kanalize edilmeli. Yani daha böyle bir yetiştirici, geliştirici, bilgilendirici, bilinçlendirici aile eğitimlerine yer verilmesi gibi bir durumdan geçmesi lazım. Yoksa hani şu anda verilen piktes uygulaması da var. Bu kadar yapılan hizmetlerin karşılığını çok az öğrenci gösteriyor. Hani daha çok farklı noktalardan eğitime bakılıyor. Ailelerin bakışı biraz daha farklı noktalarda, eğitim değil.” Ô.2
\end{abstract}

\subsubsection{Materyal destekleri}

Katılımcı öğretmenlerin bahsettiği diğer bir husus da materyal destekleridir. Bu konu ile ilgili Piktes projesinde görev yapan öğretmenler uzaktan eğitim döneminde yabancı uyruklu öğrenciler için

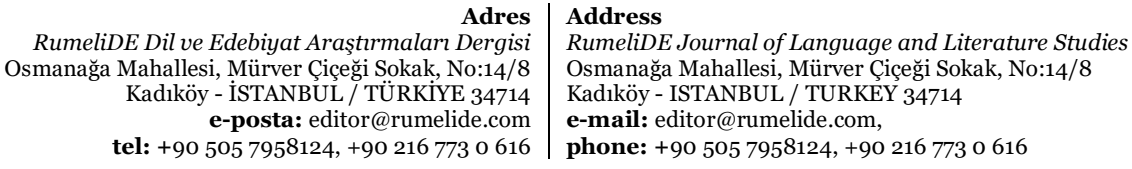


hazırlanmış Türkçe ders kitabının gönderildiğinden ancak diğer dersler ile ilgili ders kitabının gönderilmediğinden bahsetmişlerdir. Aynı zamanda katılımcı öğretmenlerden bazıları günlük hayatta öğrencilerin karşlaşabileceği kelimelerin görsellerinden oluşturulmuş, seviyeye göre hazırlanmış materyal setlerinden bahsetmişlerdir. Bu setlerin de derslerde kullanıldığından ve yararlandığından bahseden öğretmenler olduğu gibi, setlerdeki resimlerin boyutundan ötürü verimli kullanamadıklarını ifade eden öğretmenler de olmuştur. Örgün eğitim veren öğretmenler ise yabancı uyruklu öğrenciler ile ilgili “özel” bir materyalin kendilerine sağlanmadığını belirtmişlerdir. Konu ile ilgili P.4 şu yorumda bulunmuştur;

\begin{abstract}
"Bize Nasrettin Hoca ile ilgili, ondan sonra birçok böyle tarihin böyle sürekli hepimizin hayatında izler bırakmış şahsiyetlerin Arapça Türkçe hikayeler vardı. Bunlar bende vardı, Öğrenci sayıma da yeterliydi. Ben bunları her öğrencime dağıttım okula bıraktım” P.4
\end{abstract}

\title{
3.1.7 Bilgilendirme çalışmaları
}

Katılımcı öğretmenler bilgilendirme çalışmaları hakkında okul olarak çeşitli faaliyetler yürüttüklerini ancak daha geniş çapta faaliyetlerin yürütülmediğinden bahsetmişlerdir. Yapılan faaliyetlerin bir bölümünü okul rehber öğretmeni ve müdür yardımcısı tarafından organize edildiğini bahsetmişlerdir. Özellikle sürecin başında yoğun olarak veliler ile iletişim kurduklarını bahseden öğretmenler olduğu gibi herhangi bir veli bilgilendirme çalışması faaliyetini gerçekleştirdiğini belirten öğretmenler de olmuştur. Bakanlığın bilgilendirici faaliyetleri konusunda ise bakanlık tarafından çevirmen ve tercümanlar vasıtası ile “Arapça videolar” çekilerek Eba'nın kullanımı ile ilgili paylaşımlar yapıldığını belirtmişlerdir. Yapılan doküman analizleri sırasında Eba TV yayın akışının da bakanlık tarafından Arapça tercümesinin bulunduğu ve güncellenerek il koordinasyon ekipleri tarafindan paylaşıldığı görülmüş̧tür. Yapılan bilgilendirme çalışmaları ile ilgili katılımcı öğretmenler yabancı uyruklu öğrenci velileri ile "iletişim sorunları" yaşadıklarını ya da "katılım ya da geri dönüş olmadığını" belirtmişledir.

\subsection{Uzaktan eğitimde ders süreci ve etkileyen faktörler}

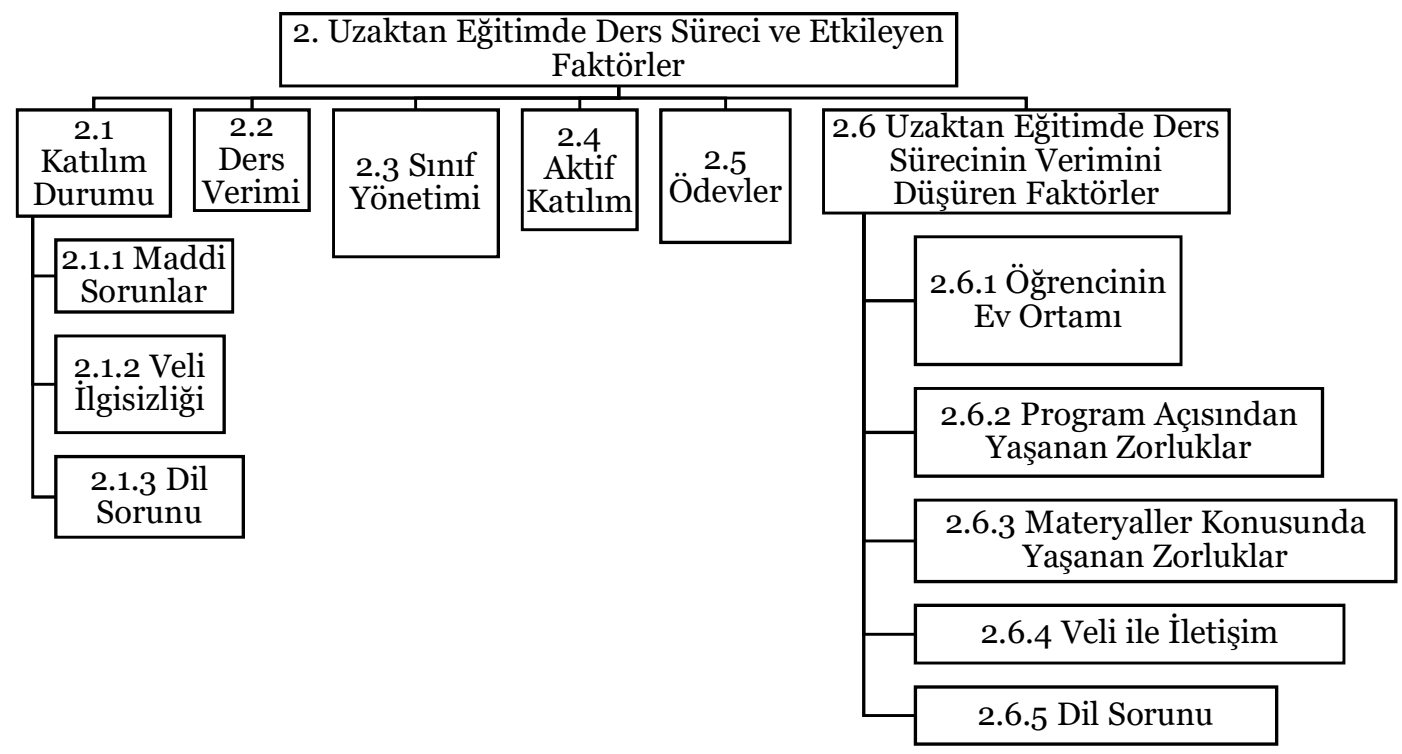

Şekil 3: Uzaktan eğitimde ders süreci ve etkileyen faktörler

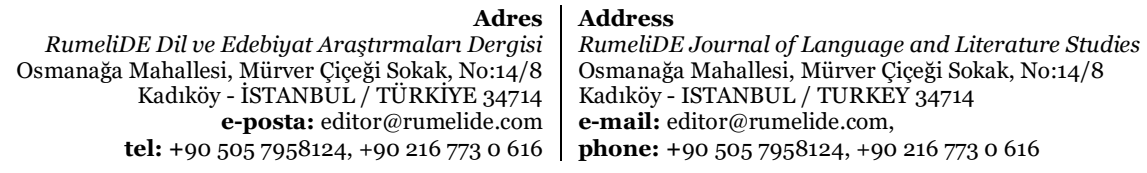


Katılımcı öğretmenler ile yapılan görüşmelerde uzaktan eğitimde ders süreci incelendiğinde, katılımcı öğretmenlerin görüsslerinin katılım durumu, ders verimi, sınıf yönetimi, aktif katılım, ödev verimi ve uzaktan eğitimde ders sürecinin verimini düşüren faktörler şeklinde alt temalar oluşturduğu görülmüş̧ür.

\subsubsection{Katılım durumu}

Katılımcı öğretmenler uzaktan eğitim sürecinde yabancı uyruklu öğrencilerin derse katılımında azalma gözlemlediklerini belirtmişlerdir. Katılımda azalmanın boyutu incelendiğinde Piktes Projesinde görev yapan öğretmenlerden bazıları "10 yabancı uyruklu öğrenciden 5-6 tanesinin" uzaktan eğitim sürecine katılım gösterdiğini belirtirken, "6o öğrenciden 3 tane öğrencinin" uzaktan eğitim sürecine katıldığını belirten öğretmen de bulunmaktadır. Örgün eğitim veren öğretmenlerin sınıflarında bu denli yüksek sayıda yabancı uyruklu öğrenci olmamasına karşın yabancı uyruklu öğrencilerin bu süreçte sürekli devamsızlık ya da düzensiz katılım sağladıklarını belirtmişlerdir. Bu konudaki görüşler incelendiğinde yabancı uyruklu öğrencilerin uzaktan eğitime katılımının örgün eğitime göre en az yarı yarıya düştüğü görülmektedir. Örgün eğitim sürecinde "öğrencilerle birebir ilgilenme olanağı olduğunu" ve katılımı sağladıklarını, uzaktan eğitimde böyle bir olanak olmadığından dolayı "çocukların katılmak istemediğini” belirtmişlerdir. Ancak uzaktan eğitim sürecinde bu denli azalmalardan bahsetmelerine rağmen yabancı uyruklu öğrencilerin okulun açı olduğu dönemlerde düzenli katılım gösterdiğini de eklemişlerdir. Ö.7 ve P.4 katılımda azalmayı şu şekilde ifade etmişlerdir;

"Bir tanesinin katılımı \%10o uzaktan eğitim sürecinde. O çok aktif bir öğrenci, fakat diğer ikisi uzaktan eğitim derslerine girmediler. İki tane kız, bir tane erkek öğrencim var, kızlardan bir tanesi \%100 katılım yaptı erkek öğrencim ise çok nadiren girdi, telefon kullanıyor her şeyi biliyor ama biraz geri kaldı istemedi çok fazla katılmayı. Diğer kız öğrencim hiç katılmadı.” Ö.7

"Mesela 10 öğrenci varsa ortalama 5-6 en az 5-6 öğrenci katılım gösteriyor ya da 20 öğrenci varsa 1 tane öğrenci katılım gösteriyordu. Ben buna şahit oldum.” P.4

\subsubsection{Maddi sorunlar}

Katılımcı öğretmenlerin görüşleri incelendiğinde uzaktan eğitim sürecine yabancı uyruklu öğrencilerin katılmama sebeplerinin başında en yüksek frekans oranıyla bahsettikleri hususun maddi sorunlar olduğu görülmüştür. Katılımcı öğretmenler yabancı uyruklu öğrencilerinin sosyoekonomik olarak altorta düzeyde yer aldığını belirtmektelerdir. Öğrenciler arasında "ailelerine ekonomik olarak katkı sağlayan, babasıyla birlikte işe giden" öğrencilerin bulunduğunu, ailelerin "kalabalık ve tek maaşla geçinmeye çalıştıklarından” bahsetmişlerdir. Katılımcı öğretmenlerden P.1 sosyoekonomik düzey ile ilgili şöyle bir yorumda bulunmuştur;

"Ziyaret ettiğim öğrencilerim oldu. Yani öyle çok çok durumu iyi olan çocuklar değiller. Geneli yaşam mücadelesi içinde olan insanlar.” (P.1)

Katılımcı öğretmenler uzaktan eğitim sürecine katılmayan öğrencilerin maddi sorunlarını; cihaz eksikliği ve internet bağlantısı sorunları olarak belirtmiş̧lerdir. "Bilgisayar, tablet gibi araçlardan yoksun" olduklarını, öğrencilerin "çoğunluğunun" bilgisayarı ya da tableti bulunmadığından ötürü telefondan uzaktan eğitime katıldıklarından bahsetmişlerdir. Öğrencilerin anne veya babalarının telefonuyla uzaktan eğitime katılsalar dahi "babanın işe gittiği” durumlarda öğrencilerin uzaktan eğitim faaliyetlerine katılamadıklarını belirtmişledir. Bakanlığın cihaz desteği çalışmalarının olduğu, maddi imkansızlıklar yaşayan öğrencilerini istenen listeye dahil ettiklerini ancak kendi öğrencilerine ya da okullarındaki herhangi bir yabancı uyruklu öğrenciye böyle bir cihaz desteğinin bulunmadı̆̆ını, bu

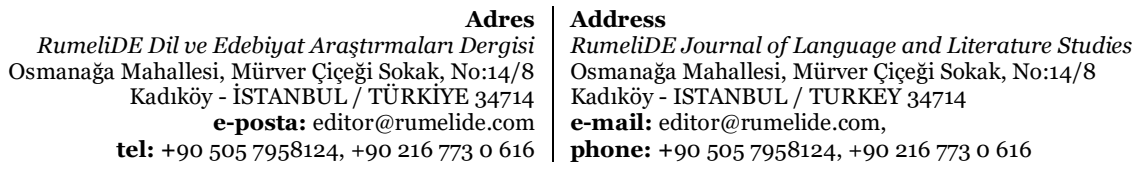


desteğin "her öğrenciye ulaşmadığını” belirtmişlerdir. Katılımcı öğretmenlerin bahsettiği diğer bir husus da cihaz sayısının yetersizliğinden dolayı ders çakışmaları durumudur. Katılımcı öğretmenlerin tamamına yakını yabancı uyruklu öğrencilerin kalabalık ailelere sahip olduğunu ve çocukların genellikle kardeşleri ile arasında yaş farkı olmadığından dolayı kardeşlerinin de uzaktan eğitime devam ettiği ancak derslerin çakışması durumunda evdeki cihaz sayısının yetersizliğinden dolayı öğrencilerin uzaktan eğitime devam edemediklerini ya da düzeniz katılım gösterdiğini belirtmişlerdir.

Bahsedilen ikinci maddi sorun ise internet bağlantısı sorunlarıdır. Öğretmenler yabancı uyruklu öğrencilerin katılımları ile ilgili yaptıkları görüşmelerde evde kullanabileceği bir cihaz olsa dahi internetlerinin olmadığını belirtmişlerdir. Öğrencilerin mobil internet ya da "komşularının internetlerinden" uzaktan eğitime katılmaya çalıştıklarını ancak mobil internetin kotasının dolduğu durumlarda öğrencilerin "kotanın yenilenmesini beklediklerini” belirtmişlerdir. Bu konu ile ilgili P.4 şöyle bir yorumda bulunmuştur;

“Çocuklarm evinde internet yok, televizyon yani tablet yok, bilgisayar yok. Yani iletişim kurabileceğimiz sadece burada mısın? Ondan sonra aynı şehirde miyiz? tarzında ilk etapta böyle oldu. Çünkü çoğunun evinde internet yoktu.” (P.4)

\subsubsection{Veli ilgisizliği}

Katılımcı öğretmenler yabancı uyruklu öğrencilerin uzaktan eğitim sürecine katılmama sebeplerinden bir diğerinin de veli ilgisizliği olduğunu düşünmektelerdir. Yine katılımcı öğretmenlerin tamamı öğrencilerin sabit internet ve cihaz sorunu gibi maddi sorunlar yaşamadıklarını durumlarda velilerin ilgisiz davranıp öğrencileri uzaktan eğitim sürecine dahil etmediklerini belirtmişlerdir. Bu konu ile ilgili P.5 şu yorumda bulunmuştur;

"Maddi sebepten de bir tane öğrencim annesinin telefonu çok dolu olduğunu söylüyor. O yüzden Eba’yı yüklemediğini Zoom yüklemediğini söylüyor. Yani bu hani artık derse gelmemek için bahane diye düşünüyorum. Telefonu dolu ne demek başka bir uygulama silersiniz onu yüklersiniz yani bilmiyorum bir tek o var ama o da maddi sıkıntıdan dolayı değil.” (P.5)

Katılımcı öğretmenler velilerden uzaktan eğitim süreci ile ilgili yeterli desteği göremediklerinden, maddi sorunlar olmasa bile öğrencilerin derse katılmadığından bahsetmişlerdir. Bu konu ile ilgili "çocukları derse sokmadıklarından" yakınmakta, velilerin "ekonomik sıkıntıları olduğundan dolayı çocukların eğitime vakit ayıramadığını” düşünmektelerdir. Veliler ile katılım sağlamak konusunda iletişim kurduklarını ve Eba destek noktaları hakkında bilgi verdiklerini ancak velilerin öğrencileri Eba destek noktasına getirmediklerini söylemişlerdir. Maddi imkansızlıkları olsa dahi Eba destek noktaları kullanamama sebepleri olarak "velilerin eğitime önem vermediklerini", çocukların eğitim alması yönünde çaba harcamadıklarını açıklamışlardır. Bu konu ile ilgili Ö.2 şöyle bir yorumda bulunmuştur.

"Yani aslında ailenin bu ihtiyaçları giderilirken ailenin birazcık böyle taşın altına elini koyup, bari eğitime yatırım yapayım gibi bir düşünce yok maalesef. ........ Her şeyi devletten bekliyorlar, yani burada yapılsın gibisinden görülüyor. Aynı şekilde eğitimi de öğretmenden bekliyor........ Ailelerin yani hani devletten beklentileri yüksek, okuldan beklentileri yüksek ya da bu iş okulun işi gibisinden. Belki kendi kültürlerinde öyle. Kendileri taşın altına elini koymak istemiyorlar. Bunun da birçok sebebi olabilir. Hani bi boşvermişlik görüyorum." (Ö.2)

\subsubsection{Dil kaynaklı sorunlar}

Katılımcı öğretmenlerin daha düşük frekansta bahsettikleri diğer bir husus da dil kaynaklı sorunlardır. Yeterli Türkçe dil becerisine sahip olmayan öğrenci ve velilerin uzaktan eğitime geçişte büyük sorunlar

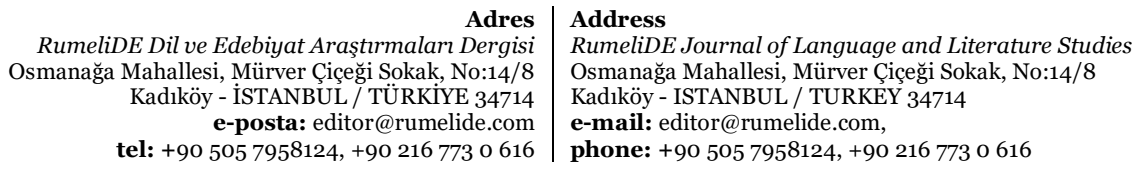


yaşadığını ve Eba sistemine giriş yapmakta ve kullanmakta zorluklar yaşadıklarından ötürü uzaktan eğitim faaliyetlerine katılamadıklarını ifade etmişlerdir. Bu konu ile ilgili P.3 şöyle bir yorumda bulunmuştur;

\begin{abstract}
"Çocuk zaten her halükârda hani okula gidebildiği kadar eğitim alıyor. Ekstraları kısıtlı birinci sınıf düzeyinde tek kelime Türkçe bilmiyor. Hani imkânı varsa bile telefondan ya da bilgisayardan EBA uygulamasını açıp ya benim gönderdiğim linki bir şekilde derse katılım sağlayabilecek bir düzeyi yok." (Ö.3)
\end{abstract}

\title{
3.2.2 Ders verimi
}

Ders verimi konusunda katılımcı öğretmenlerin görüşleri; uzaktan eğitim faaliyetlerine devam edildiği taktirde ilerleme sağlandığı ancak genel olarak ders veriminde düşüş yaşadıkları yönündedir. Ancak öğretmenler yeterli dil seviyesine sahip öğrencilerin düzenli katılım gösterdiği takdirde sorun yaşamadıklarını da belirtmişlerdir. Öğretmenler uzaktan eğitim sürecinin örgün eğitim kadar verimli olmadığını düşünmektedirler. Araştırmaya katılan bir öğretmen hariç tüm öğretmenler uzaktan eğitim sürecinde verim kaybı yaşadığından bahsetmiştir. Uzaktan eğitim sürecini P.3 "yerinde saymak" olarak tanımlamakta, uzaktan eğitim sürecinde öğrencilere "yeni şeyler eklemenin zor olduğunu" belirtmektedir. Uzaktan eğitim sürecinde öğrencilerle "temas halinde olamadıklarını", farklı seviye gruplarından oluşan yabancı uyruklu öğrencilerle "özel olarak ilgilenemediklerini”, 6 saat boyunca bilgisayardan dersleri takip etmenin öğrenciler açısından "zor ve yıpratıcı" olduğunu belirtmişlerdir. Motivasyon da öğrencilerin derse olan tutumlarını etkileyen önemli bir faktördür. $\mathrm{Bu}$ süreçte öğrencilerin motivasyonlarının düştüğünü belirtmişlerdir. Uzaktan eğitim sürecinde verim düşüşü yaşandığı konusunda katılımcı öğretmenler hemfikir olsalar da online materyallerin kullanılabilmesi gibi etkenler sayesinde "düzenli” katılım gösteren öğrencilerin "okuma-yazma” öğrenebilecek derecede verimli olduğunu da eklemişlerdir. Bu konu ile ilgili P.1 şöyle bir yorumda bulunmuştur;

\begin{abstract}
"Uzaktan da olsa eğitimde karşılık alıyoruz. Bir ilerleme kaydediyoruz ama işte burada çocukları olaya katabilmek mesela çocuk birkaç gün gözükmüyor. Soruyorum diyorum ki işte, hani niye katılmadım işte babam işe gitti. Babam işe gitti için telefon yoktu derse katılamadım diye çocuk mesela. Katıldıkları zaman yavaş da olsa az da olsa bir gelişme kat ediyoruz ama dediğim gibi burada çocukların katılabilmesi, önemli olan o.” (P.1)
\end{abstract}

\subsubsection{Sinıf yönetimi}

Sınıf yönetimi konusunda katılımcı öğretmenlerlesin tamamı zorluk yaşadıklarından bahsetmişlerdir. Sanal sınıflarda dersi bölen konuşma ve uygulamalara izin vermediklerini belirten öğretmenler dersin akışını rahatlıkla devam ettirebildiklerinden bahsetmekle beraber ses gelmesi durumunda sesi kapatıp derse devam etseler dahi kamera ve mikrofonun aynı anda kapalı olması durumunda öğrencilerin canlı dersi dinlerken dikkatlerini toplayamadıklarını, kimi zaman öğrencilerin "yaratak" ders işlediklerine şahit olduklarını belirtmişlerdir. Görüntü kapalı olduğu taktirde "çocuğun çıkıp gitmiş olabileceği” ya da "başka bir şeyle ilgileniyor olabileceği" gibi endişelerinin olduğunu, öğrenciler her ne kadar derste olsa da dersi dinleyip dinlemedikleri konusunda emin olmadıkları görülmüş̧ür. Katılımcı P.5 bu durumu şöyle ifade etmektedir;

"Zümre toplantıları oluyor Genel sınıf öğretmenlerinin ona katılmıştım, orada bir hocamızın söylediği çok hoşuma gitmişti. Yüz yüze eğitimden daha iyi, sessize basiyorum, hepsinin sesi kesiliyor demişti. Yani gerçekten öyle. Yani kendi aralarında kavgaya falan kalkarsa genelde ben sesleri açık yapıyorum ama Arapça konuşmaya başladıkları zaman çok sorun oluyor.” (P.5)

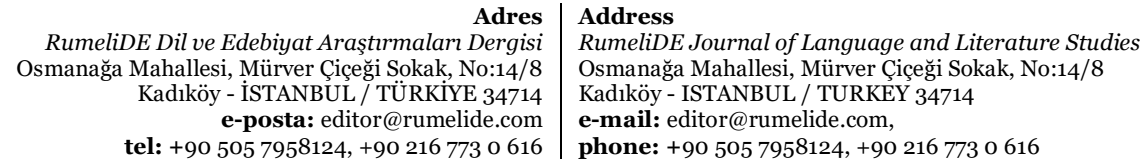

RumeliDE Dil ve Edebiyat Araştırmaları Dergis tel: +90 505 7958124, +90 2167730616 


\subsubsection{Aktif katılım}

Aktif katılım konusunda öğretmenler aktif katılımın önemli olduğunu belirtmekle beraber, kimi öğretmen aktif katılım konusunda sorun yaşamadığını belirtmekte iken kimi öğretmen "soru sorduğundan yanıt alamadığını”, aktif katılım sağlamada güçlük yaşadığını belirtmiştir. Derse aktif katılımı sağlamak amacıyla öğretmenler sıra ile söz hakkı verdiklerini, etkinlikleri bir arada yapıp oyun oynadıklarını ve bu şekillerde aktif katılım sağlamak konusunda öğrencileri teşvik ettiklerinden bahsetmişlerdir. Aktif katılım durumu ile ilgili Ö.5 ve Ö.2 şu yorumlarda bulunmuşlardır;

“Örgünde daha iyiydi. Örgünde sorduğum soruya cevap alabiliyordum ama uzaktan olduğu zaman yazıyordu çiziyordu ama sorularıma cevap vermek için mikrofonunu açmıyordu.” Ö.5

"Uzaktan eğitim sürecinde öğrencimiz bunda hem dil problemi hem sınıfın seviyesinden geriden gelme durumundan dolayı dinleyici pozisyonunda kaldı. Çok aktif katılım sağlayamadı.” Ö.2

\subsection{5 Ödevler}

Ödevler ve görevler gün içinde yapılan öğrenmelerin pekiştirilmesi ve tekrarı yönündeki önemli uygulamalardır. Uzaktan eğitim sürecinde ödevler konusunda öğretmenler “düşüş” yaşadıklarını iletmişlerdir. Ödevleri sosyal medya uygulamalarından öğrencilere gönderdiklerini belirten öğretmenler, ödevlerin kontrolünü yine sosyal medya ortamından ve derslerde gerçekleştirdiklerini belirtmişlerdir. Ödevler konusunda öğrencilerin uzaktan eğitim sürecinde örgün eğitime nazaran daha çok "bahane" ürettiğini belirten öğretmenler, örgün eğitimde ödevleri çalışma kâğıdı gibi şekillerde verip, öğrencinin gözü önünde kontrolünü sağlamanın daha verimli olduğunu ancak uzaktan eğitim sürecinde bu verimi yakalayamadıklarını belirtmişlerdir. Ayrıca uzaktan eğitim sürecinde ödevler konusunda güdüleyici faktörleri kullanamadıklarından dolayı ödevlerin yapılmadığı ya da veriminin düşük olduğu konusunda görüşlerini beyan etmişlerdir. Öğrencilerinin ödev yapmaması ile ilgili düşüncelerini P.1 şu şekilde ifade etmiştir;

"Yani işte yaptıkları sayfaların işte resimlerine işte atıp göndermelerini filan istiyoruz. Ama genelde çok konsantre değiller. Öyle söyleyeyim. Şimdi okulda biz kendimiz kendi imkânlarımız ile birtakım etkinlikler oluşturuyoruz. Çocuğun eline kâğıt olarak veriyoruz. Bunu yarın da hem kontrol ediyoruz hem de işte oraya ben ne bileyim gülen surat, yıldız falan bu tür bu tarz şeyler belki yetişkinler için çok anlamlı olmuyor ama çocukların hoşuna gidiyor. Bu tür geri dönüşler küçük de olsa motive ediyor. Çocuğa bunları yaptığımız zaman şey alıyoruz Hani geri dönüt alıyoruz, çocuk yapıyor bunu. Ama işte uzaktan eğitimle, çocuk buna konsantre olamıyor. Öyle söyleyeyim.” P.1

\subsubsection{Uzaktan eğitimde ders sürecinin verimini düşüren faktörler}

Öğretmenlerin uzaktan eğitimde ders sürecinde yaşadıkları verimsizliğin sebepleri incelendiğinde öğrencinin ev ortamı, program açısından yaşanan sorunlar, materyaller açısından yaşanan sorunlar, iletişim sorunları olduğu görülmüştür.

\subsubsection{1 Öğrencin ev ortamı}

Öğretmenlerin görüşleri incelendiğinde ders sürecinde verimi düşüren faktörlerin başında öğrencinin ev ortamı olduğu görülmüştür. Katılımcı öğretmenler sosyoekonomik düzeyin yarattığı maddi etkiler etkisi ve yabancı uyruklu öğrencilerin kalabalık ailelere sahip olmasından ötürü kendi odaları ya da çalışma masaları olmadığından bahsetmişlerdir. Ö̆̆rencilerin kendi odaları olmamasından dolayı ortak kullanım alanlarında derse katıldığını belirtmişlerdir. Bu durum ile ilgili Ö.5 "Ben bir kardeşini kamera açtığında her defasında gördüm, hep yanındaydı kardeşi ve biraz da problem yaratıyordu” şeklinde bir

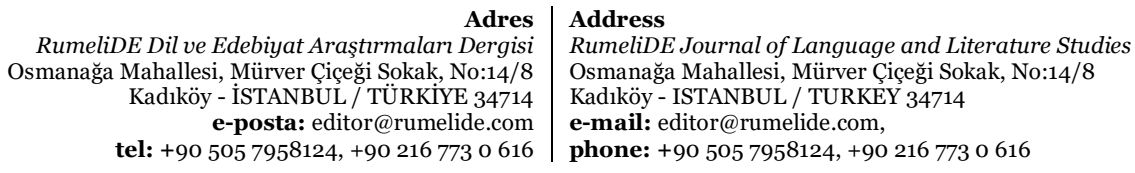


yorumda bulunmuştur. Özellikle evdeki ortamdan kaynaklı kardeşlerinin ya da öğrenci velilerinin "çocuğun ilgisini dağıttı̆̆ını" belirten öğretmenler, bu durumun ders verimini etkileyen bir faktör olduğunu belirtmektedirler. Ö.4 ve P.2 şöyle bir yorumlarda bulunmuşlardır;

"Evde Türkçe konuşmuyorlar. Kendi dillerinde konuşuyorlar. Müthiş bir gürültü var ondan sonra çocuktan anlayamıyor bizim söylemek istediklerimizi.” (Ö.4)

"Kalabalık ortamda ders yapıyorlar. Çoğu zaman kardeşlerini falan sesini duyuyorum ben. O yüzden sesi kapatmak durumunda kalıyorum.” P.2

\title{
3.2.6.2 Program açısından yaşanan zorluklar
}

Program açısından yaşanan zorluklar konusunda katılımcı 2 grubun fikir ayrılığı yaşadığı görülmektedir. Örgün eğitim veren öğretmenler programların Türkçe dil becerilerine sahip öğrencilere uygun olduğunu ve bu konuda zorluklarla karşılaşmadıklarını belirtmişlerdir. Piktes projesinde görev yapan öğretmenler ise program açısından zorluklar yaşadıklarını belirtmişlerdir. Öğrencilerin dil seviyesindeki yetersizlik sebebiyle proje kapsamında eğitim aldığını, Türkçe derslerinde programın öğrencinin dil becerilerini geliştirmeye uygun olduğunu ve öğrencilere bir şeyler kattığını ancak fen bilgisi, matematik gibi derslerde öğrencilerin Türkçe dil becerilerini aşan programları öğrencilerin takip etmekte güçlük yaşadıklarını belirtmişlerdir. Piktes Projesi kapsamında görev yapan öğretmenler sınıflarına öğrencilerin Türkçe dil becerisi eksik öğrencilerin geldiğini ancak bu öğrencilere yine kendi sınıflarına uygun bir program kullanmakta zorlandıklarını belirtmişlerdir. Bu konu ile ilgili P.2 şu yorumda bulunmuştur;

“Türkçe açısından müfredat uygun ama diğer dersler açısından bizim normal Türk öğrencilere vermemiz gereken müfredatın vermemizi istiyorlar. Bu da zaten pek mümkün olmuyor. Mesela ben diğer derslerde konu seçiyorum. Daha sonra konuları işliyorum mesela hani fen bilgisi her konuyu işleyemiyorum.” (P.2)

Program konusunda sorun yaşamadığını belirten P.5 ise programı kendine öğrenciye göre düzenlediğini ve kullandığını, bu sayede program konusunda sorun yaşamadığını şu şekilde belirtmiştir;

\begin{abstract}
"Müfredat konusunda bir sıkıntı yaşamıyoruz. Yani biz genelde müfredatı kendinize göre ayarlıyoruz çocukların seviyesine göre çocuk nerde kaldıysa tekrar aynı yerden devam ediyoruz. Yani müfredat şurada diye illa orada yapmak zorunda değiliz. Zaten öyle bir şey zorunlu öyle bir şey yapmaya kalkarsa çocuk bir şey öğrenemez.” (P.5)
\end{abstract}

\subsubsection{Materyaller konusunda yaşanan zorluklar}

Ders verimini etkileyen diğer bir faktör olarak belirtilen materyaller konusunda öğretmenlerin iki farklı görüşe sahip olduğu görülmüştür. Bu görüşlerden ilki materyaller konusunda zorluk yaşamadığını belirten öğretmenler, uzaktan eğitim sürecinde öğrencinin evde olduğundan dolayı günlük hayatta karşılaştıkları eşyalar gibi konularda daha rahat bir öğretim gerçekleştirebildiklerini aynı zamanda online öğretim materyallerinin dersi somutlaştırma konusunda oldukça destek sağladığını belirtmiş̧lerdir. Millî Eğitim Bakanlığı tarafından sağlanan ders kitaplarının yeterli olduğunu eklemişlerdir. Materyaller konusunda zorluklar yaşadığını belirten öğretmenler ise, ders kitaplarındaki yönergeleri yabancı uyruklu öğrencilerin anlamasına uygun olmadığını ve öğrencilerin kafalarının karıştı̆̆ını, online materyal geliştirmede güçlükler yaşadıklarını, öğrenci seviyesine uygun online materyal bulmakta zorluklar yaşadıklarını, Piktes projesi kapsamında dağıtılan kitapların geç dağıtıldığını ve Türkçe hariç diğer dersler için basılı kaynak dağıtılmadığı ile kitapların okuma-yazma konusunda eksik olduğunu, ifade etmişlerdir.

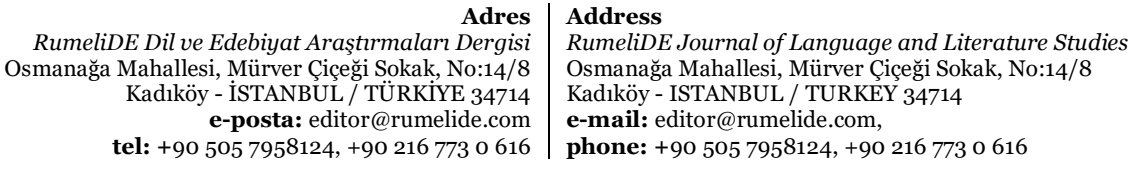

RumeliDE Journal of Language and Literature Studies

Osmanağa Mahallesi, Mürver Çiçeği Sokak, No:14/8

Kadıköy - ISTANBUL / TURKEY 34714

e-mail: editor@rumelide.com

phone: +90 505 7958124, +90 2167730616 


\title{
3.2.6.4 Veli ile iletişim sorunları
}

Yabancı uyruklu öğrencilerin ders sürecini etkileyen diğer bir faktöründe veliler ile iletişim sağlamada yaşanan zorluklar olduğu görülmüştür. Katılımcı tüm öğretmenler “veli ilgisizliğinin” yanında veliler ile iletişim kurmakta yaşadıkları güçlüklerden bahsetmişlerdir. Uzaktan eğitimde öğrenciler evde olduğu için veli desteği önemli bir etkendir. Bu hususla ilgili öğretmenler veli ile iletişimlerinin zaylf olduğunu ve ulaşmakta zorluklar yaşadıklarını aktarmışlardır. Veli ile iletişim konusunda kurulan sosyal medya gruplarından "velilerin çıktığını" ve velilerin Türkçe bilmemesinden dolayı öğrenci ya da diğer 3. kişiler vasıtası ile veli iletişimi kurulmaya çalışıldığını ancak bu durumunda da veli ile iletişimde kopukluk yarattığını belirtmişlerdir. Velilerin Türkçe bilmesi durumunda öğrencilerin de Türkçe konusunda daha başarılı olduğunu belirten öğretmenler bu durumda veli desteğinden faydalanamadıklarını ifade etmişlerdir. Bu konu ile ilgili P.1 ve Ö.7 şöyle bir yorumda bulunmuştur;

\begin{abstract}
“Anlaşamıyoruz çünkü şey yapıyor mesela veli tamam diyor, öğrenci gelecek diyor. Herhangi bir sıkıntı mesela şey soruyoruz, biz internetiniz var mı? Evde cihaz var mı? Hani bilgisayar, telefon ya da tablet? Velinin bana söylediği her şeye tamam diyor ama çocuk ortalıkta bu sefer şunu soruyorum, acaba anlamadan mı tamam dedi Bana veli, yoksa anlayıp da mı tamam dedi, onu tam çözemiyoruz (P.1)."

"Çok fazla iletişime geçemedim. Kendisi de çok fazla anlamıyor ailesi hiç anlamıyor. Bu defa da araya mesafe girdi, O da bana ulaşamıyor" (Ö.7)
\end{abstract}

\subsubsection{Dil sorunu}

Özellikle örgün eğitim veren öğretmenlerin görüşleri incelendiğinde, dersleri takip etmek için yeterli Türkçe dil seviyesine sahip olmayan öğrencilerin "dersleri anlamakta güçlük yaşadıklarını" ve "canlı dersleri takip etme şansı olmadığını” belirtmişlerdir. Bu sebeple uzaktan eğitimden zamanla kopan öğrenciler olduğunu da eklemişlerdir. Örgün eğitim veren öğretmenlerin görüşleri incelendiğinde 1. Sınıftan itibaren aynı sınıfta yer alan ve düzenli katılım gösteren öğrencilerin Türkçe dil becerilerini geliştirdiklerinden dolayı büyük sorunlar yaşamamalarına karşın, özellikle ara sınıflarda katılım gösteren ya da yeni 1. Sınıfa başlayan öğrencilerde dil gelişimini uzaktan eğitimde sağlayamadıklarını belirtmişlerdir. Piktes projesinde çalışan öğretmenler derslerde dil sorunu yaşadıklarından bahsetmemişlerdir. Piktes Projesinde özellikle dersler dil gelişimine odaklandığı ve bir çerçeve plana tabi olduklarından dolayı ilerleme sağlanırken, örgün eğitimde öğretmenlerin takip etmeleri gereken bir program olduğundan dolayı "dil gelişimi” ya da "kelime öğretimi” yapacak imkanları bulamadıklarını, öğrencilerin örgün eğitim sırasında özellikle "akranları sayesinde" ve "sınıf içinde birebir Türkçeye maruz kalarak” dil öğreniminin yapıldığı belirtmişlerdir. Yaşadıkları dil engelini Ö.5 ve Ö.8 şu şekilde ifade etmişlerdir;

"Hiç söylediğimi de anlamıyor mesela hayat bilgisi kitabını çıkartın diyorum o matematik kitabını çıkartıyor. Yani konuşmamı da anlamıyor kitabı gösteriyordum ben de. Haliyle dersleri de takip edemiyordu.” Ö.5

"Birinci sınıftan beri benim öğrencim olan çocuk Türkçeyi düzgün öğrendikten sonra normal öğrenci düzeyinde katılım sağladı. Şu anda normal bir dördüncü sınıf öğrencisi gibi sınava girebiliyor ve her şeyi yapabiliyor fakat diğer çocuk üçüncü sınıfın ikinci döneminde daha öncesinde hiç okula bile başlamadan direkt benim sınıfıma geldi. Çocuğu daha önce göndermemişler Türkçe de bilmiyor ancak çat pat Türkçe öğrenebildi, canlı derslere katılmadı. Geldiği zamanda da ancak birkaç tane harf verebildim. Türkçe bilmiyor zaten oradan takip etme şansı yok geldiği zaman ben birkaç tane harf verip o şekilde takip edebildim zaten normal sınıf düzeyinde de değil. Suriyelileri başka bir okula alıp eğitim veriyorlar ama ona da denk gelmedi üçüncü sınıfları aldılar bizimki dördüncü sınıftaydı hep geri kaldı." Ö.8

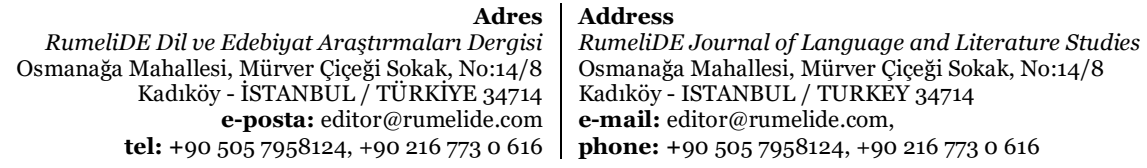

Adres
RumeliDE Dil ve Edebiyat Araştırmaları Dergisi tel: +90 505 7958124, +902167730616 


\subsection{Beklenti ve çözüm önerileri}

Katılımcı öğretmenlerin yabancı uyruklu öğrencilerin uzaktan eğitime çekme ve dersin verimini arttırma konusunda; maddi sıkıntıların aşılması konusunda çalışmalar yapılması, veli desteği, Eba içeriğinin yabancı öğrencilere uygun içeriklerle doldurulması, velilere Türkçe eğitimi, seviyeye uygun program hazırlanılması, dil seviye gruplarının daha belirgin olması, daha kaliteli materyaller hazırlanılması, yaz kurslarının seviye grupları şeklinde açılması, uzaktan eğitimde kullanılabilecek yöntem ve tekniklerle ilgili hizmet içi eğitimler verilmesi, öğrencilere psikolojik yardım ve rehberlik faaliyetleri sunulması ve öğretmen güdüleyici çalışmaların yapılması, öğrencilere dil gelişimi için destek sağlanması, Eba destek noktalarının ve yaz kurslarının yaygınlaştıılması şeklinde beklenti ve çözüm önerileri olduğundan bahsetmişlerdir.

\section{Sonuç, tartışma ve öneriler}

Yabancı uyruklu öğrencilerin uzaktan eğitim sürecinin incelendiği bu çalışmada Milli Eğitim Bakanlığının pek çok çalışma gerçekleştirdiği görülebilir. Yapılan çalışmalarla ilgili bulgular incelendiğinde Eba içeriğinin öğretmenler tarafından beğenildiği ve ilk okuma etkinliklerinin yabancı uyruklu öğrencilere uygun olduğunu sonucu elde edilmiştir. Ayrıca "yabancılar için Türkçe" dersi kapsamında yeterli içeriğin henüz oluşturulmadığı ve öğretmenlerin Dil Öğretim Portalı hakkında yeterli bilgiye sahip olmadığı tespit edilmiştir. Kesin ve Baş (2021) da bu çalışmanın bulgularıyla paralel olarak Eba içeriğinin ilk okuma yazma sürecinde avantajlar sağladığından bahsetmişlerdir. Korkmaz ve İnal (2019) teknoloji tabanlı eğitsel oyunların dil öğreniminde geleneksel yöntemlere göre daha etkili olduğunu tespit etmiştir. Bahçeci ve Efe (2018) öğrencilerin Eba'yı kullanma sılklı̆ının az olduğunu tespit etmiş ve bunun arkasında sebebin de içeriğinin yetersiz olabileceğini belirtmişlerdir. Yabancılara Türkçe öğretimi konusu ilkokul kademesinde nispeten yeni bir konu olduğundan bu içerikler henüz oluşturulmamış olabileceği düşünülmektedir.

Trt Eba Tv hakkında öğretmenlerin içerikten memnun olduğu ancak içeriğin sunumu -dersin anlatılışının ilgi çekici olmadığı- konusunda eleştirilere sahip oldukları sonucuna ulaşılmıştır. Ayrıca örgün eğitim veren öğretmenler "yabancllar için Türkçe” dersinin Eba Tv'ye eklendiğini ve içeriğini bilmemektedirler. Katılımcı tüm öğretmenlerin öğrencilere Eba Tv'yi tavsiye edip bu konuda teşvik ettikleri ancak yabancı uyruklu öğrencilerden geri dönüt alamadıkları görülmektedir. Öztürk ve Çetinkaya (2021) televizyon izlenme oranlarını inceleyerek öğrencilerin uzaktan eğitim sürecinde Eba Tv'ye yoğun ilgi gösterdiğini tespit etmiştir. Kurnaz, Kaynar, Şentürk Barışık ve Doğrukök (2020) de Eba Tv derslerinin öğrencilerin dikkatini toplayamadığını belirtmişlerdir. Yabancı uyruklu öğrencilerin evlerinde kimi zaman Türk kanal sistemi kurulu olmadığından, yabancı uyruklu öğrenciler Trt Eba Tv'ye ulaşmakta güçlük yaşayabilir. Ayrıca Eba Tv’ye yabancılar için Türkçe dersinin yeni eklenmesi sebebiyle öğrenciler daha önceden yayınlanan derslerin seviyelerine uygun olmadığını düşünüp takip etmemiş de olabilirler.

Yabancı uyruklu öğrencileri Eba destek noktalarına yönlendirdiği ancak öğrencilerin Eba destek noktalarını kullanmadıkları sonucuna ulaşılmıştır. Yabancı uyruklu öğrenci velilerin ilgisizliğine dair çalışmalar bulunmaktadır (Ünal ve Aladağ, 2020). Yabancı uyruklu öğrenci velileri maddi imkansızlıklar, evdeki kardeş sayısının çokluğu ve eğitim konusundaki ilgisizlikleri nedeniyle öğrencileri Eba destek noktalarından faydalanmamış olabilirler.

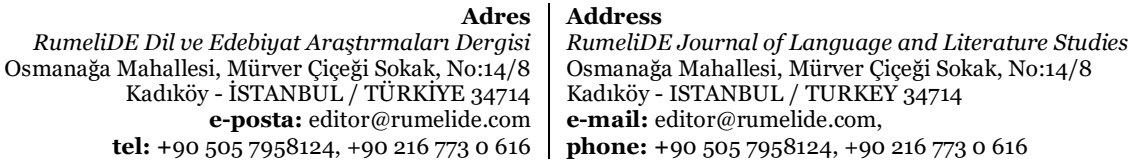

Adres
RumeliDE Dil ve Edebiyat Araşttrmaları Dergisi ä̈̈̈ - İT tel: +90 $5057958124,+902167730616$

phone: +90 505 7958124, +90 2167730616 
Milli Eğitim Bakanlı̆̆ının uzaktan eğitim sürecinde pek çok hizmet içi eğitimler sağladığını ve bu eğitimlere yabancı uyruklu öğrencilerin eğitimi konusunun da dahil olduğu sonucuna ulaşılmıştır. Ancak örgün eğitim veren öğretmenlerin çoğunluğunun bu eğitimden faydalanmadı̆̆ı tespit edilmiştir. Başaran ve diğerleri (2021) pandemi döneminde öğretmenlere zorunlu bir hizmet içi eğitim verilmediğini, öğretmenlerin şahsi istekleri ile çeşitli eğitimlere katıldığını belirtmiştir. Yabancı uyruklu öğrencilere Türkçe eğitimi konusu öğretmenlerin ilgisini çekmemiş olabileceğinden öğretmenler bu eğitimden faydalanmamış olabilir.

Materyal desteğinin sadece Piktes öğretmenlerine yapıldığı, örgün eğitim veren öğretmenlere bu süreçte bir materyal desteği sağlanmadığı görüşüne sahip oldukları görülmüştür. MEB (2021) resmi web sitesi incelendiğinde etkinlik kitapları haricinde basılı materyal gönderimi sağlanmamış olsa dahi uzaktan eğitim süreci için pek çok e-kitap ve materyal paylaşılmıştır. Öğretmenler bu hizmetler hakkında yeterince bilgilendirmemiş olabilir. Aynı zamanda öğretmenlerin materyal kelimesini "yazılı ve basılı" materyal olarak yorumlamış olabilirler.

Yabancı uyruklu öğrencilere uzaktan eğitim ders süreci incelendiğinde katılımın azaldığı sonucuna ulaşılmıştır. Uzaktan eğitimde katılımın azalma gösterdiğine dair çalışmalar bulunmaktadır (Erkoca, 2021; Saygl, 2021). Katılımın azalmasının ana sebebinin öğrencilerin maddi imkansızlıkları ve veli ilgisizliği olduğu sonucu elde edilmiştir. Maddi imkansızlıkların başında cihaz ve internetin olmaması gelmekle beraber evdeki öğrenci sayının fazlalığı nedeniyle ders çakışmalarının yaşandığı tespit edilmiştir. Alanyazın incelendiğinde (Agaton ve Cueto, 2021; Akça ve Akgün, 2020; Kabapınar, Kanyılmaz, Koçhan ve Atik, 2021) uzaktan eğitimdeki maddi imkansızlıkların etkisinden bahsedilmiştir. Kabapınar, Kanyılmaz, Koçhan ve Atik (2021) de bu çalışmanın bulgularıyla paralel şekilde öğretmenlerin derse katılımdaki azalmada velilerin ilgisizliğinin ve kardeş sayısının etkisinden bahsetmiştir. Ancak Akça ve Akgün (2020) ailelerin uzaktan eğitimde yeterli desteği sağladığını belirtmiş̧ir. Bu çalışmanın bulguları ile ters çıkan bu sonucun sebebinin yabancı uyruklu öğrenci velilerinin eğitime daha az önem vermeleri olabilir.

Öğretmenlerin görüşleri incelendiğinde uzaktan eğitimde ders veriminin azaldığ Öğrenci yeterli Türkçe dil becerisine sahipse derslerden verim alındığı, ancak ara dönemde gelen ve okula yeni başlayan öğrencilerin yeterli Türkçe dil becerilerine sahip olmamasından ötürü dersleri anlamlandıramadıkları ve verim alamadıkları sonucuna ulaşılmıştır. Güngör ve Şenel (2018) tömer öğrencileri ile yapmış oldukları çalışmada yabancı uyruklu öğrencilerin uzaktan eğitiminde etkileşimin sınırlı olduğunu ve dil becerilerini geliştirmede yetersiz olduğunu belirttiğini ifade etmiştir. Tucker (2001) ise üniversitesi öğrencileri ile yapmış olduğu çalışmasında verimin yüz yüze eğitim ile benzer olduğu sonucuna ulaşmıştır. Bu farkın öğrencilerin sınıf kademesinden oluştuğu düşünülmektedir. İlkokul öğrencilerinin farkındalı̆̆ının düşük olmasından dolayı derslere gereken önemi verememiş olabilirler.

Öğretmenlerin aktif katılımı sırayla söz hakkı vererek sağladıkları ancak yabancı uyruklu öğrencilerin dersi anlamlandırmada yaşadıkları sorundan dolayı pasif kaldıkları durumlar olduğu sonucu elde edilmiştir. Koç (2021) da çalışmasında uzaktan eğitim sürecinde aktif katılımın istenilen düzeyde olmadığını belirtmiştir. Uzaktan eğitim sürecinde öğretmen-öğrenci etkileşiminin azalması, öğrencilerin motivasyon kaybı ve ev ortamındaki dikkat dağıtıcı unsurların varlığı öğrencilerin aktif katılımını etkileyebilir.

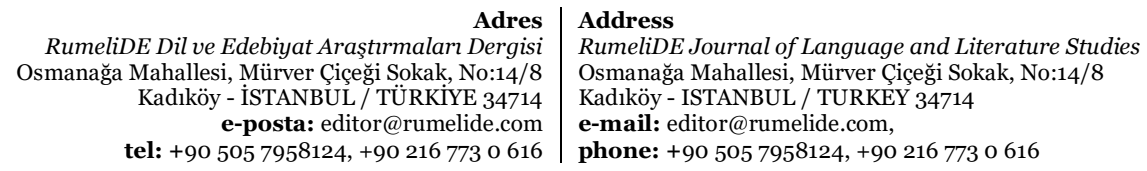


Ders verimini düşüren faktörlerden ilki olarak öğrencilerin kalabalık ailelere sahip olmaları sebebiyle ortak kullanım alanlarında derse girdiği, evlerin çok gürültülü olduğu ve kardeşlerinin öğrencileri rahatsız ettiği sonucuna ulaşılmıştır. Alanyazın incelendiğinde (Kamer ve Sarıahmetoğlu, 2020; Tümkaya ve Çopur, 2020) yabancı uyruklu öğrencilerin maddi sorunlar yaşadığı görülmektedir. Yapılan araştırmalara göre Suriyeli kadınların doğum oranının 5.3’tür (Yılmaz, 2020). Bu oran Suriyeli çocukların ortalama 5'den fazla kardeşi olduğu şeklinde yorumlanabilir. Hem maddi güçlükler sebebiyle birden çok ailenin bir arada yaşadı̆̆ı kalabalık aile durumları, hem de yüksek doğum oranı sebebiyle kardeş sayısının etkisinin evlerin öğrencilerin eğitimi için uygun bir ortam olmadığı görüşünü pekiştirebilir.

Örgün eğitim veren öğretmenler uzaktan eğitim sürecinde program açısından zorluklar yaşamazken, Piktes öğretmenlerinin program açısından zorluklar yaşadığı tespit edilmiştir. Alanyazın incelendiğinde (Gültutan ve Kan, 2019; Koçoğlu ve Yelken, 2018) yabancı uyruklu öğrencilere örgün eğitim sürecinde öğretim programın yönünde yaşanan zorluklara dair çalışmalar bulunmaktadır. Örgün eğitim veren öğretmenlerin alanyazın ile uyuşmayan bu sonucun, bu çalışmada ve alanyazında öğretmenlerin eğitim verdikleri öğrencilerdeki Türkçe dil becerilerindeki farklılıklar sebebiyle oluşabileceği düşünülmektedir.

\section{Öneriler}

-Yabancı uyruklu öğrencilerin uzaktan eğitime daha aktif katılımının sağlanması adına maddi sorunları ortadan kaldıracak cihaz yardımı, internet desteği gibi çalışmalar yapılmalıdır.

-Yabancı uyruklu öğrencilerin eğitiminde en çok bahsedilen sorunlardan biri olan veli ilgisizliği konusunda velilere bilinçlendirme çalışmaları yapılmalıdır.

-Uzaktan eğitime katılım sağlayamayan yabancı uyruklu öğrenciler için örgün yaz kursları düzenlenmelidir.

-Yapılan çalışmalar hakkında öğretmen ve velilerin bilgilendirilmesine özen gösterilmeli ve bu çalışmaları kullanmaları yönünde teşvik edilmelidir.

-Sınıfında yabancı uyruklu öğrenci bulunan öğretmenler için hizmet içi eğitimler zorunlu hale getirilmelidir. Ayrıca bu eğitimlerin içeriği derinleştirilmelidir.

-Ara sınıflarda gelen ya da dil bilmeden sınıf atlayan öğrenciler için Piktes Projesinin kapsamı genişletilmeli, her öğrencinin ilk olarak dil engelinin kaldırılmasına özen gösterilmelidir.

\section{Kaynakça}

Agaton, C. B. ve Cueto, L. J. (2021). Learning at home: Parents' lived experiences on distance learning during COVID-19 pandemic in the Philippines. International Journal of Evaluation and Research in Education, 10(3), 901-911. doi:10.11591/ijere.v10i3.21136

Akça, G. ve Akgün, E. (2020). İlkokul Öğrencilerinin Uzaktan Eğitim Sürecinde Yaşadığı Sıkıntılar. EJERCongress 2020 Conference Proceedings, 402-409.

Alyılmaz, C. (2010). Türkçe Öğretiminin Sorunları. Journal of Turkish Studies, Volume 5 I(5), 728-749. doi:10.7827/TurkishStudies.1629

Bahçeci, F. ve Efe, B. (2018). Öğrencilerin Eğitim Bilişim Ağı (EBA) Sitesine Yönelik Görüşlerinin Değerlendirilmesi. Kuramsal Eğitimbilim, 11(4), 676-692. doi:10.30831/akukeg.387055

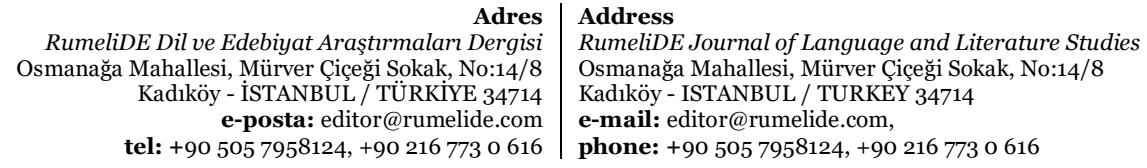


Başaran, M., Ülger, I. G., Demirtaş, M., Kara, E., Geyik, C. ve Vural, Ö. F. (2021). Uzaktan Eğitim Sürecinde Öğretmenlerin Teknoloji Kullanım Durumlarının İncelenmesi. OPUS Uluslararası Toplum Araştırmaları Dergisi, 17(37), 4619-4645. doi:10.26466/opus.903870

Boylu, E. ve Işık, P. (2020). Suriyeli Mültecilerin Yoğun Olarak Yaşadığı İllerde Türkçe Öğrenme Süreçleri Üzerine Öğretmen Görüşleri. Abant İzzet Baysal Üniversitesi Eğitim Fakültesi Dergisi, 20(2), 1113-1128. doi:10.17240/aibuefd.2020..-641783

Cirıt Karaağaç, F. ve Güvenç, H. (2019). Resmi İlkokullara Devam Eden Suriyeli Mülteci Öğrencilerin Eğitim Sorunları. OPUS Uluslararası Toplum Araştırmaları Dergisi, 11(18), 530-568. doi:10.26466/opus.530733

Creswell, J. W. (2020). Nitel Araştırma Yöntemleri, Beş Yaklaşıma Göre Nitel Araştırma ve Araştırma Deseni. (S. B. Demir ve M. Bütün, Ed.). Ankara: Siyasal.

Derince, D. (2019). Suriyeli Mülteci Çocuklar Özelinde: Savaş Mağduru Çocuklar ee Çocuk Sağlı̆̆ı Sorunları. Bandırma Onyedi Eylül Üniversitesi Sağllk Bilimleri ve Araştırmaları Dergisi, 1(1), 5770.

Diab, S. Y., Palosaari, E. ve Punamäki, R. L. (2018). Society, individual, family, and school factors contributing to child mental health in war: The ecological-theory perspective. Child Abuse and Neglect, 84(May 2017), 205-216. doi:10.1016/j.chiabu.2018.07.033

Ehntholt, K. A., Smith, P. A. ve Yule, W. (2005). School-based cognitive-behavioural therapy group intervention for refugee children who have experienced war-related trauma. Clinical Child Psychology and Psychiatry, 10(2), 235-250. doi:10.1177/1359104505051214

Ergen, H. ve Şahin, E. (2019). Sınıf Öğretmenlerinin Suriyeli Öğrencilerin Eğitimi İle İlgili Yaşadıkları Problemler. Mustafa Kemal Üniversitesi Sosyal Bilimler Enstitüsü Dergisi, 16(44), 377-405.

Erkoca, M. C. (2021). Uzaktan eğitim sürecinde öğrenci ilgisi - bir çalışma. Açıöğretim Uygulamaları ve Araştırmaları Dergisi, 7(1), 148-163.

Eroğlu, M. (2020). Etnik Kimlik, Savaş ve Göç Olgularının Çocuklar ve Ergenler Üzerindeki Psikolojik Etkileri. Uluslararası Sosyal Bilgilerde Yeni Yaklaşımlar Dergisi (IJONASS), 4(1), 94-105. doi:10.38015/sbyy.721964

GİGM. (2020). Geçici Koruma İstatistikleri. Erişim Tarihi: 9 Kasım 2020 Erişim Adresi: https://www.goc.gov.tr/gecici-koruma5638.

Gültutan, S. ve Kan, M. O. (2019). Türkiye'de ilkokulda öğrenim gören Suriyeli öğrencilerin yazma becerisine ilişkin öğretmen görüşleri. Okuma Yazma Eğitimi Araştırmaları, 7(2), 71-86. doi:10.35233/oyea.648597

Güngör, F. ve Şenel, E. A. (2018). Yabancı Uyruklu İlkokul Öğrencilerinin Eğitim - Öğretiminde Yaşanan Sorunlara İlişkin Öğretmen ve Öğrenci Görüssleri. Anadolu Journal of Educational Sciences International, 8(2), 124-173. doi:10.18039/AJESI.454575

HBOGM. (2020). 2019 Yılı İzleme ve Değerlendirme Raporu. Hayat Boyu Öğrenme Genel Müdürlüğü. Ankara. Erişim Adresi:

http://hbogm.meb.gov.tr/dosyalar/izlemedegerlendirmerapor/2019/mobile/index.html.

Kabapınar, Y., Kanyılmaz, B. M., Koçhan, N. Ö. ve Atik, U. (2021). Öğretmen ve Velilerin Gözünden Öğrencilerin Uzaktan Eğitime Katılımlarının Öyküleri: "Uzaktan Ĕgitim mi, Uzakta Kalan Eğitim mi?” Temel Eğitim Araştırmaları Dergisi, 1(1), 79-98. doi:10.29228/mutead.6

Kamer, S. T. ve Sarıahmetoğlu, H. (2020). Yabancı Uyruklu Ortaokul Öğrencilerinin Eğitim Sürecinde Karşılaştıkları Sorunlara İlişkin Görüşleri. Elektronik Sosyal Bilimler Dergisi, 19(76), 1611-1630. doi:10.17755/esosder.709695

Kara, Ö. T., Tiğit, A. ve Ağırman, F. (2020). Batman İl Merkezinde Çalışan Türkçe Öğreticilerinin Karşılaştıkları Sorunlar. Çukurova Üniversitesi Türkoloji Araştırmaları Dergisi, 5(2), 577-599. doi:10.32321/cutad.785028

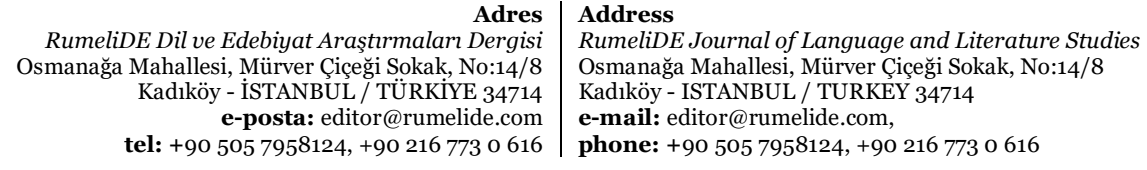


Kesin, C. ve Baş, Ö. (2021). Sınıf Öğretmenlerinin Perspektifinden Eba ve Eğitim Portalları İle İlk Okuma Ve Yazma Öğretimi. Eğitim Teknolojisi Kuram ve Uygulama, 11(1), 93-115. doi:10.17943/etku.769901

Koç, E. S. (2021). Nasıl Bir Uzaktan Eğitim? 1 Yılın Sonunda Yapılan Çalışmaların Değerlendirilmesi. Sosyal Bilimler Dergisi, 7(2), 13-26.

Koçoğlu, A. ve Yelken, T. Y. (2018). Suriyeli Öğrencilere Türkçe Dil Becerileri Kazandırma Sürecinde İlkokul Türkçe Dersi Öğretim Programları İle İlgili Öğretmen Görüşleri. Eğitimde Nitel Araştırmalar Dergisi, 6(2), 131-160.

Koehler, C. ve Schneider, J. (2019). Young refugees in education: the particular challenges of school systems in Europe. Comparative Migration Studies, 7(28). doi:10.1186/s40878-019-0129-3

Korkmaz, Ö. ve İnal, M. (2019). Eğitsel Oyunların Öğrencilerin Yabancı Dil Olarak Türkçe Öğrenmeye Dönük Tutumlarına ve Konuşma Becerilerine Etkisi. Ana Dili Eğitimi Dergisi, 7(4), 898-913. doi:10.16916/aded.582203

Kurnaz, A., Kaynar, H., Şentürk Barışık, C. ve Doğrukök, B. (2020). Öğretmenlerin Uzaktan Eğitime İlişkin Görüşleri. Milli Eğitim Dergisi, 49(1), 293-322. doi:10.37669/milliegitim.787959

MEB. (2020). Uzaktan Eğitim Sürecinin Detayları. Erişim Tarihi: 5 Mayss 2021 Erişim Adresi: https://www.meb.gov.tr/uzaktan-egitim-surecinin-detaylari/haber/21990/tr.

MEB Uzaktan Eğitim. (2021).MEB. Erişim Tarihi: 15 Haziran 2021 Erişim Adresi: https://uzaktanegitim.meb.gov.tr/.

Merriam, S. B. (2018). Nitel Araştırma: Desen ve Uygulama İçin Bir Rehber. Nobel Akademik.

OMDUSMANLIK. (2018). Türkiye'deki Suriyeliler. T.C KAMU DENETÇİLİĞİ KURUMU. Erişim Adresi:https://www.ombudsman.gov.tr/document/raporlar/ozel_raporlar/suriye_rapor/index. html.

Özenç, E. G. ve Saat, F. (2019). Sınıf Öğretmenlerinin Suriyeli Öğrencilerin Eğitiminde Karşılaştığı Sorunlar, 4(2), 60-74.

Öztürk, B. ve Çetinkaya, A. (2021). Pandemi Döneminde Bir Eğitim Aracı Olarak Televizyon: Trt Eba Tv. İNIF E - Dergi, 6(1), 140-162. doi:10.47107/inifedergi.886813

Rousseau, C., Drapeau, A. ve Corin, E. (1996). School performance and emotional problems in refugee children. American Journal of Orthopsychiatry, 66(2), 239-251. doi:10.1037/hoo80175

Saygı, H. (2021). Kovid-19 pandemi uzaktan eğitim sürecinde sınıf öğretmenlerinin karşılaştığı sorunlar. Açıköğretim Uygulamaları ve Araştırmaları Dergisi, 7(2), 109-129. doi:10.51948/auad.841632

T.C. İçişleri Bakanlığı. (2021). Erişim Tarihi: 5 Mayıs 2021 Erişim Adresi:https://www.icisleri.gov.tr/.

TUBİTAK. (2020). Sıkça Sorulan Sorular | COVID-19 Türkiye Web Portalı. Erişim Adresi: https://covid19.tubitak.gov.tr/covid19/sikca-sorulan-sorular.

Tucker, S. (2001). Distance Education: Better, Worse, or As Good As Traditional Education? Online Journal of Distance Learning Administration, 4(4).

Tümkaya, S. ve Çopur, E. (2020). Suriyeli Ailelerin İlkokulda Aile Katılımına İlişkin Öğretmen Görüşleri. Çukurova Üniversitesi Sosyal Bilimler Enstitüsü Dergisi, 29(3), 368-386. doi:10.35379/cusosbil.746471

Tunga, Y., Ergin, G. ve Çağıltay, K. (2020). Türkiye'deki Suriyeli Çocukların Eğitiminde Karşılaşılan Sorunlar Üzerine Bir Alanyazın Taraması. İnönü Üniversitesi Ĕgitim Fakültesi Dergisi, 21(1), 317333. doi:10.17679/inuefd.535845

Ünal, R. ve Aladağ, S. (2020). Kapsayıcı Eğitim Uygulamaları Bağlamında Sorunlar ve Çözüm Önerilerinin Incelenmesi. Journal Of Interdisciplinary Education: Theory and Practice, 2(1), 2342.

UNHCR. (2020a). Trends At A Glance: Global Trends Forced Displacement İn 2019. UNHCR. Erişim Adresi: https://www.unhcr.org/5ee200e37.pdf.

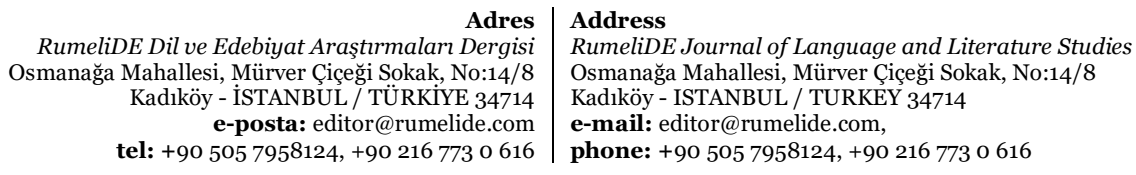


UNHCR. (2020b). Türkiye'deki Mülteciler ve Sığınmacılar - UNHCR Turkey. Erişim Tarihi: 29 Kasım 2020 Erişim Adresi: https://www.unhcr.org/tr/turkiyedeki-multeciler-ve-siginmacilar.

Yavuz, Ö. ve Mızrak, S. (2016). Acil Durumlarda Okul Çağındaki Çocukların Eğitimi: Türkiye’deki Suriyeli Mülteciler Örneği. Göç Dergisi, 3(2), 175-199. doi:10.33182/gd.v3i2.578

Yıldırım, A. ve Şimşek, H. (2018). Sosyal Bilimlerde Nitel Arastirma Yontemleri (8. bs.). Ankara: Seçkin.

Yılmaz, V. (2020). Pandemi Öncesi ve Sirasında Türkiye’de Cinsel Sağlık ve Üreme Să̆lığı Hizmetleri İzleme Raporu. Erişim Adresi: https://cisuplatform.org.tr/wp-

content/uploads/2020/10/Pandemi-Oncesi-ve-Sirasinda-Turkiyede-CSUS-Hizmetleri-IzlemeRaporu-web.pdf.

RumeliDE Dil ve Edebiyat Araştırmaları Dergisi Osmană̆a Mahallesi, Mürver Çiçeği Sokak, No:14/8 Kadıköy - ÍSTANBUL / TÜRKIYE 34714 e-posta: editor@rumelide.com tel: +90 $5057958124,+902167730616$
Address

RumeliDE Journal of Language and Literature Studies Osmanağa Mahallesi, Mürver Çiçeği Sokak, No:14/8

Kadıköy - ISTANBUL / TURKEY 34714

e-mail: editor@rumelide.com,

phone: +90 505 7958124, +90 2167730616 